\title{
Rahvalik muusika eesti rahvuskultuuri osana
}

Guldžahon Jussufi

Teesid: Kõikeühendava emakeele kõrval leidub kultuurinähtusi, mis samuti, võib-olla küll mitte keele moodi kategooriliselt, kuid ometi näitavad inimese kuulumist teatud rahva hulka. Muusika seisab nende nähtuste esireas ja enamasti ei ole see rahvamuusika. Võib tunduda imelikuna, et tänapäeval ei ole rahvamuusika eriti populaarne nende rahvaste endi seas, kes on selle loonud. Nüüdisajal on varasema rahvamuusika positsiooni hõivanud ajaviitekultuuri avarustelt rahvuskultuuride pinnasele üle kandunud muusika, mis üleilmselt levivate ja kiires tempos vahelduvate muusikastiilide varjus püsib elujõulise ning stabiilsena. Eesti rahvalik muusika kuulub just selliste, rahvakultuuri pinnasel edukalt juurdunud uuemaaegsete muusikastiilide hulka.

Märksõnad: pillimees, rahvalik laul, rahvalik muusika, seltskonnalaul

\section{Teabeallikaist}

Rahvalik muusika on Eesti kultuuris nii igapäevane ja iseenesestmõistetav, samal ajal tähtsusetuks peetav nähtus, et siiani ei ole tuntud vajadust üles tähendada selle muusikastiili kujunemislugu. Seda sõnaühenditki kohtab trükitekstides harva ja seetõttu on rahvaliku muusika arenguteed keeruline jälgida. Leidub ainult kaudseid allikaid - üsnagi habras lähtepunkt üldistuste ja järelduste tegemiseks.

Esmajoones pean silmas Valter Ojakääru, kellelt siiani on ilmunud kolm sisutihedat mälestusteost (Ojakäär 2000, 2003, 2008). Neist võib kasulikku teavet ammutada džässisõber, kultuuriloolane, koduloolane, ajaloolane jne. Ega asjata ole Valter Ojakääru kohta öeldud "eesti levimuusika Balthasar Russow". Tõsi, rahvalikku muusikat tema teostes eraldi teemana ei leia, raamatud käsitlevad levimuusikat laiemas mõistes. Aga kuna rahvalik muusika on adapteerinud paljude levimuusika žanride meloodiaid, võib V. Ojakääru raamatuid lugeda kui rahvaliku muusikastiili kujunemise kroonikat. 
Valve Saretoki (1956) põhjalikult läbi mõeldud ja suurepäraselt sõnastatud mälestustes leiame kireva ja üksikasjaliku, otse ruumilise pildi Eesti 1920.1930. aastate koolielust. Autor talutab lugejat algkooli esimesest klassist alates kuni gümnaasiumi lõpetamiseni. Kergesti on jälgitav koolilaste muusikalise silmaringi laienemise dünaamika, kooli, kodu ja ühiskonna osa noore põlvkonna ilumeele kujunemisel. Tähelepanu on saanud rõivamoe muutused, ühtede seltskonnatantsude vahetumine teiste vastu, saksa ja vene keele taandumine suhtlemisel, vene- ja saksakeelsete seltskonnalaulude kadumine ja eestikeelsete esiletõus, kontaktid Soome hõimukaaslastega jne. See huvitav ja ainulaadne teave on tänuväärt taustaks, mis aitab mõista rahvaliku muusika esiletõusu Eesti iseseisvumise järel.

Artur Rinne (Rinne 1973a, 1973b, 1980) mälestused annavad ettekujutuse rahvaliku laulu osast rahva identiteeditunde säilitajana. Andmeid eesti rahvakultuuri kohta olen lisaks eelnimetatutele laenanud talupoeglikust keskkonnast pärit autoreilt, kelle kirjutatu toetub isiklikele mälestustele ja kogemustele, nagu Märt Raud (1961), Gustav Ränk (1949), Herbert Tampere (1999, 2001), Juhan Aavik (1965). Pikemaid või lühemaid lõike nende teostest olen kasutanud sõnastust muutmata. Muidugi oleks võimalik teha mõnelauselisi kokkuvõtteid, et hoida kokku trükiruumi, kuid siis läheks kaduma emotsionaalne alatoon, mis möödapääsmatult saadab kõikvõimalikke meenutusi. Kui oli valida esmaste ja kompilatiivsete allikate vahel, püüdsin võimalust mööda kasutada esimesi.

\section{Termineist}

Ajaviitemuusika terminoloogia pole kaugeltki ühtne. Kohtab mõisteid, mida tarvitatakse suvaliselt, ilma et püütakski saavutada ühtlust. Igal huvirühmal, seda enam ajakirjanikul, paistab olevat oma isiklik leksikon. Seetõttu tuleb peaaegu iga ajakirjanduses ette sattuv populaarmuusikat puudutav termin lahti mõtestada kontekstist lähtuvalt - kui seda ei tee, võib jutust valesti aru saada. Leidub hulk termineid, mida kasutatakse tihti ja veendunult, kuid mille tähendus on ähmane ja ebamäärane. Selgust ei ole võimalik saada ka muusikateatmike abil. Pärast mõne sellise oskussõna iseenese tarkusega lahtimuukimist läheb tulemus sageli lahku sellest, mida sama mõiste märgib mingis teises seoses.

Et vältida segadust, tundub otstarbekohasena terminid, mida ma kasutan, kohe algul lahti seletada. Võimalust mööda toetun Eesti kirjakeele seletussõnaraamatule (EKSS), samuti Andrus Saareste Eesti keele mõistelisele sõnaraamatule, Eesti Entsüklopeediale (EE) ja, kuna kõne all on levimuusika valdkond, siis ka Valter Ojakääru muusikaalastes teostes antud määratlustele. 
Külavahelaulud, külalaulud - pilkelaulud, satiirilise pilkava sisuga naljalaulud konkreetse isiku kohta, humoristlikud lood juhtumustest külas.

Ühislaulud - rahvakogunemistel, nagu pulmad, sünnipäevad, koolikogunemised jne, üheskoos lauldavad üldtuntud laulud, mille viisi ja sõnu enamik teab. Kasutatakse ka konkreetse ürituse tarvis paljundatud tekstilehti.

Rahvamuusika - rahva pärimuslik muusikalooming (EE 1997: 676).

Levimuusika - populaarne muusika, meeleolumuusika, mida esitavad harilikult vokaal-instrumentaalansamblid, kerge muusika (EKSS 1992: 110).

Rahvalik muusika - eesti tavapärane seltskonnamuusika, tihti laulud mõne pilli saatel või esitatud ka puht instrumentaalvariandina, enamasti akordionil mängituna. Käesolevas artiklis mõistan pillimeeste all ka kanneldajaid, kelle repertuaar ja tegevus on üldjoontes samasugune kui akordioni- ja lõõtspillimängijail. Pillimees mängib üksinda, suurema osa tema repertuaarist, kui mitte kogu repertuaari, moodustab rahvalik muusika. Pillimees võtab laulu üles, tema asukoht on kolmemõõtmelises ruumis rahva keskel, mitte laval raami sees, millel on laius ja kõrgus, kuid puudub sügavus.

Rahvusvahelises terminoloogias on tehtud mõistete vahel vahet nt selle põhjal, kas muusikat tehakse kogukonnasiseselt (rahvamuusika - folk music, traditional music) või turustamiseks ja massimeedias levitamiseks (populaarmuusika, levimuusika - popular music) (The New Grove 9: 67). Eesti rahvaliku muusika puhul ei ole selline eristus aga võimalik, sest ühed ja samad muusikapalad kõlavad nii rahvasuus kui ka massimeedias ja helikandjatel, liikudes vabalt ühest sfäärist teise.

\section{Välitööd: kui kogemus on kasutu}

Minu varasem välitööde kogemus pärineb Tadžikistanist, kus enamasti tegelesin pamiiri rahvaste instrumentaalmuusika uurimusega. Seal puudub vajadus eeltööde järele, pole vaja hankida andmeid, kas paikades, kuhu kavatsed minna, leidub pillimehi. Kaugeltki igas majas ei oota sind särtsu täis moosekant, pill käesirutuse kaugusel, kuid tasub vaid küsida, kui sulle loetakse ette terve rida pillimehi, kelle seast igaüks on küla parim - kiitma ei olda kunagi kitsi. Sinu otsustada jääb, kuhu minna varem ja keda jätta hiljemaks.

Mõni kindlasti solvub, kui enne teda külastad kedagi teist. Järjega temani jõudes võib eest leida jonnaka põikpea, kes kinnitab, et tema pole üldse mingi pillimees, ei oska midagi, vahel ajaviiteks ainult näpib keeli. Muidugi, pikapeale meelekibedus möödub, ta mängib ja laulab, nii et lust kuulda, kuid sinnani võib minna mitu päeva. Niisiis on parim võimalus paluda pillimehed kokku majja, kuhu juhuse tahtel esmalt sisse astusid. 
Juba lippavadki tulijalgsed poisikesed sõna laiali kandma. Sellist kutset ei lükata tagasi, järgmine võimalus jäädvustada oma kunsti helilindile tulevaste põlvede tarvis võib jääda hoopiski tulemata. Varsti on tuba pillimehi ja muidu uudishimulikke kuivalt täis, jääb üle ainult kärmesti linte vahetada. Sündmusest kujuneb omamoodi võistumängimine, kuigi juttu sellest ei tehta. Juhtub, et mõne aja pärast haaravad pilli ka need tagasihoidlikud hinged, kes algul ajasid kahe käega vastu ja kinnitasid, et nemad ei oska midagi. Küsimusi esitada ja püüda asjade käiku enda järgi suunata ei maksa. Hiljem, kui hoog on raugenud, rahvas kesköö paiku laiali läinud ja teie lebate oma asemel, on piisavalt aega enne uinumist läbi mõelda, mis jäi arusaamatuks ja mille kohta pärida selgitust.

Asunud 2006. aastal tööle Eesti Kirjandusmuuseumi etnomusikoloogia osakonda, sain uurimisteemaks traditsioonilise kandlemuusika. Millest alustada? Eesti Rahvaluule Arhiivi fonoteeki on talletatud ligikaudu 1500 kandlepala, lisaks kandled laulude saatepillina ja ansamblites teiste pillidega. Kogu seda rikkust korraga ette võtta pole mõeldav. Seetõttu, pidanud nõu kolleegidega, otsustasin piirduda Võrumaa kandlemängijatega. Täienduseks arhiivis leiduvale muusikale lootsin salvestada veel tegutsevate pillimeeste mängu. Kuid eeltööna, et leida võti kandlelugude käsitlemiseks muusikateooria vahendite abil, oli vaja noodistada olemasolevate helisalvestuste see osa, mis tundus vajalik edaspidiseks tööks (Jussufi 2007: 87).

Noodistatud kujul leidub arhiivis ainult viiskümmend kandlepala. Esimesed nelikümmend noodistust tegi Armas Otto Väisänen möödunud sajandi algul, aastail 1912-1913, Setumaale ja põhjarannikule sooritatud kogumisretkedelt toodud helisalvestiste põhjal. Algmaterjaliks olid etnograafilise kuuekeelse kandle lood, mille mängutehnika erineb oluliselt tänapäeval kasutusel olevate kannelde omast. Ülejäänud kümme noodistust on teinud Herbert Tampere 1936. aastal.

Kavandades oma esimest väljasõitu, sirvisin aastakümnete jooksul rahvamuusika kogumiseks korraldatud ekspeditsioonide päevikuid. Võib näha, et varem töötasid ka eesti folkloristid mulle tuttaval kombel: sõideti mõnda maakohta ja otsiti pillimehed üles ringküsitluse teel. Tänapäeval on olukord teine: pillimeeste seltskond on jäänud hõredaks, järelkasvu pole eriti märgata. Minu senine kogemus osutus kasutuks.

Otsida pillimehi huupi ringi liikudes ja inimestelt pärides tähendaks nüüdsel ajal tohutut ajakadu. Mõistlik on nad aegsasti välja selgitada. Tänu uuema aja kommunikatsioonivahenditele pole see keeruline. Internetis leidub pillimeistrite nimekirju koos kontaktandmetega, aga et meistrid on enamasti ka arvestatavad pillimehed, pole kellelegi uudis. Neid pillimehi, kes ise pille ei valmista, on veidi raskem tabada, kuid nad jätavad jälgi ja seegi ülesanne on 
lahendatav toolilt tõusmata. Mõningaid leidsin nende sisse mängitud CDde järgi, mõningate lugusid saab Internetis isegi kuulata.

Suureks kasuks tuli Elo Kalda koostatud register, kuhu on kantud ligikaudu kahesaja kandlemängija nimed, kelle mängu salvestisi leidub kirjandusmuuseumi fonoteegis (Kalda 2001). Sünniaastaid vaadates sai kohe selgeks, et enamikuga neist enam kokku saada ei õnnestu. Valisin välja neli inimest, kelle vanus salvestamise hetkel, aastal 1984, jäi kahekümne viie ja kolmekümne viie vahele. Kõik nad olid mänginud ainult kaks lugu. Hiljem, kui asjaosaliste endiga kohtusin, selgus, et salvestised pärinevad ühelt Rakveres peetud rahvakunstiülevaatuselt. $\mathrm{Mu}$ varasem mõte, et nad ainult kaht lugu oskasidki, sai seega ümber lükatud - ülevaatusel rohkem ei nõutud. Praegu on neist neljast noorim neljakümne üheksa aastane, ülejäänud kuuekümne ja seitsmekümne vahel. Põhjus, miks register näitab nii vähest arvu mind huvitava vanuserühma pillimehi, on tõenäoliselt asjaolu, et folkloristid on eelistanud vanemat põlvkonda. Nooremaid vist ei püütudki eriti leida, sest minu sõelale jäänuistki oli ainult ühte salvestatud välitööde käigus.

Nimekirjas leiduvate elukohaviidete ja telefoniraamatu abil õnnestus kolm kanneldajat üles leida - kaks elavad Raplamaal, kolmas Tallinnas. Kahe juba elatanud Võrumaa kandlemeheni, kelle nime registris ei kohta, kuid kes kuuluvad eelmainitutega samasse vanuserühma, jõudsin nende sisse mängitud CDde abil. Nad mõlemad valdavad kandlemängu meisterlikult ja valmistavad ka ise pille. Päris ime, kuidas neil õnnestus aastakümneid mitte kohtuda folkloristidega.

\section{Pillimeeste jälgedel}

Kõik viis kandlemeest, keda kavatsesin külastada, on iseõppijad. Need, kes valdavad mitut instrumenti, nagu lõõtspill, kannel, akordion, mandoliin, eelistavad suuremale seltskonnale mängides lõõtspilli. "Lõõtsal on ikka kisa rohkem," naljatas Raplamaa pillimees Heldur Vaidla.

Antsla pillimees Ilmar Hellamaa mängib ainsana viisikannelt, ülejäänud nelja pilliks on rahvakannel. Mõnikord rahvakandle nimetusena esinev 'saateduuridega külakannel' peegeldab tabavalt pilli ehitust ja funktsiooni: viisikannel oleks nagu väikese akordkandlega külgipidi kokku pandud. Sellevõrra kasvab pill viisikandlest laiemaks. Viisi nopib pillimees parema käe nimetissõrmega või lipitsaga, vasaku käega tõmbab akorde juurde.

Saatekandlega käib enamasti kaasas "spikker", nagu kandlemängijad nimetavad omapäraseid noodilehti, paksust paberist pilli kumeruse järgi välja lõigatud kujundeid, millel on noodimärgid ja akordide nimetused, mida oma- 
korda ühendab loo skeem - graafikutaoline siksakjoon. Spikker lükatakse keelte alla, tihedalt vastu pilli ranti, nii et noodimärgid ja akordide nimetused paiknevad täpselt nende keelte all, mida on järjekorras vaja helisema panna. Selline ammust aega tuntud noot pärineb arvatavasti Saksamaalt. Juba tsaariajal andis Türil tegutsenud Avelinius Tõnissoni pillipood iga tsitriga kaasa komplekti selliseid noote. Seitse saateduuridega külakandlemängijat kaheksast kasutas spikreid, ilma saab läbi ainult üks, kes oma põhipilliks peab lõõtspilli.

Saatekandlega kaasas käiv spikker oli tõeline üllatus. Spikri kasutamist ei ole ma kanneldajate avalikel esinemistel märganud - võimalik, et pole osanud vaadata. Sellest pole kirjutatud ka rahvamuusikat kogunud ekspeditsioonide märkmetes.

Ilmar Hellamaa, keda ma 18. augustil 2008 kõigepealt külastasin, ostus vanaks tuttavaks. Temaga olime maha rääkinud pikad jutud aasta varem Viljandi pärimusmuusika festivali pillilaadal. Tal on käepärast kümmekond kannelt: akordkannel, rahvakannel, topeltkeeltega kannel ja terve sülem viisikandleid. Ühele vanemale viisikandlele on juurde kombineeritud patarei jõul töötav võimendus. Ilmar Hellamaa valmistatud viisikandleil on kakskümmend seitse keelt, neist kolm bassikeeled. Ta on teinud ka viis duuridega pilli.

Kanneldele lisaks ilmusid lagedale mitu akordionit, bajaan, karmoška, suupill ja kaks lõõtspilli, August Teppo ja Tartu meistri Karl Ostra tehtud. Võrreldes nende omadusi sõnas peremees, et Teppo pilli hääl on võimsam. Küsimusele, kumba ta neist eelistab, vastas I. Hellamaa nagu kogenud diplomaat: "Kõik on ilusad, kui hästi mängid." Kandle kiituseks ta lausus: "Väike lehm, kange piim."

Suurem osa lugudest olevat talle meelde jäänud poisikesepõlves, kuulates ema ja vanaema, kes aina laulnud. Loend, ühtekokku ehk sadakond nimetust, on kirja pandud väiksesse märkmikku.

Kõnekäänd "Kingsepal pole saabast jalas" ei käi Ilmar Hellamaa kohta kohe kindlasti. Pille tal on ja neid kõiki mängib ta suure osavusega, isegi mitut korraga: ühe käega helistab kannelt, teisega tõmbab karmoškat, mille teist otsa hoiab rihmapidi jala all. Eriti kenasti kõlab topeltkeeltega kannel, seda märkasin juba laada ajal. Seekord mängis ta seistes, asetanud kandle alla paar pappkasti paraja kõrguse saavutamiseks. Pilli alumine serv toetus kastile ja ülemine rinnale. Pilli ta hoiab lühikeste keeltega enda poole. Meeleldi kasutab tilisevat tremolot. Päris mitu korda sai läbi mängitud "Kitarre käes ja mantel üle õla”. See lugu paistab talle eriti meeldivat, kuna võimaldab efektselt kasutada viisikandle tehnilisi võimalusi, nagu glissando. Nooti ta ei tunne, aga duuride nimetusi teab. 
Kandlemeister ja pillimees Ilmar Tiideberg elab Valgamaal Sangaste vallas oma isatalus. Hariduselt on ta ehitusinsener. Ka temaga kohtusin esmakordselt pillilaadal, kuhu ta oli toonud suure akordkandle, mitu rahvakannelt, kuuekeelelise ja kümnekeelelise kandle. Viimast nimetas ta "soome kandleks".

Esimese kandle oli ta ehitanud keskkooli ajal 15-aastasena. Ühtekokku on Ilmar Tiideberg meisterdanud 33 rahvakannelt. 2000. aastal jõudis üks tema pillidest ESTO päevadele Torontos. Parajasti oli tal käsil vana pilli restaureerimine, mille sees näeb meistri nime ja valmistamisaastat: A. Madise 1929.

Ilmar Tiideberg on iseõppija, esimesed kandlepalad sai ta selgeks juba 13aastasena. Tema isa oli mänginud kannelt ja viiulit ning olnud laulumees, kuid poeg ei saanud sellest osa: ta oli 3,5-aastane, kui isa vangistati ja jäädavalt kadus. Enamiku pillimeeste vastandina, kelle esmane ülesanne on laul üles võtta ja seda pilliga toetada, on Ilmar Tiideberg instrumentalist. Oma lauluande kohta ta ütles, et "kui tahad ajada kõiki laiali, siis ma pean hakkama laulma". Pilli hoiab ta lühikeste keeltega enda poole. Viisi mängib vasaku käega, kusjuures kasutab kolme sõrme - pöialt, nimetis- ja keskmist sõrme; duure lööb parema käe nimetissõrmega, kord endast eemale, kord enda poole. Enamasti mängib ta tantsuks, kusjuures kasutab võimendust: "Publik tahab jalga keerutada ja tellib aga tantsulugusid.”

Aastatel 1967-1986 Ilmar Tiideberg ei mänginud "isikuliste raskuste tôttu", nagu ta ütles. Esinemas käib jaanipäeval, pulmades, sünnipäevadel ja muudel üritusel. Kandlemäng on teda viinud Lätti, Leetu ja Norrassegi. Enamasti mängib ta spikri abil. Ta valdab ka akordioni ja bajaani, aga põhiline on siiski kannel.

Rapla-lähedase Hagudi kandlemängija Aivar Arak pärineb Rõngust. Tema on üks nendest, kellelt 1984. aastal kaks lugu salvestati: "Kaheduuri polka" ja "Armas Maie"(RKM, Mgn II 3867, 3867). Ta on lõpetanud Eesti Põllumajanduse Akadeemia aiandusagronoomina, praegu töötab Hagudi huvikeskuse juhatajana ja juhendab kandlemängijaid mitmel pool huviringides. Muusika vastu hakkas ta huvi tundma lapsepõlves ja esimeseks pilliks oli naabripere kolme duuriga kannel. Eeskuju andsid isa, külakapelli viiuldaja, ja vana tädimees, kes mängis kannelt, kasutades päkarauda - metallist lipitsat, mis kinnitub pöidlale. "Vasaku käe pöidlal oli päkaraud ja parema käe pöidla ja nimetissõrme vahel lipits," meenutab Aivar Arak. Tema muusikaalased teadmised pärinevad põhikooli muusikatundidest. Hiljem on ta ennast täiendanud iseseisvalt, muuseas õppinud mängima süntesaatoril. Ka tema on puhtakujuline instrumentalist.

Tema väga ilusa ja võimsa kõla ning meeldiva kujundusega kannel on Tartu meistri Osvald Rossmani töö. G-duuri häälestatud pillil on 26 topeltkeelt, 
duure on viis: A, D, G, C ja F. Mängib lipitsatega, mille kinnitab teibiga mõlema käe nimetissõrmedele. Kui küsisin, kas ta jäljendab kedagi, oli vastus, et Tartus kõik mängivad lipitsaga: siis on kõla tugevam, sõrmedel ei ole valus ja nahk ei muutu paksuks. Samamoodi olevat mänginud ka Osvald Rossman.

Pill pikkade keeltega enda poole, näpib ta parema käe lipitsaga meloodiat, vasaku käe pöidlaga tõmbab duuri bassikeelt ja nimetissõrmele kinnitatud lipitsaga duuri teisi keeli. Parema käe pool on põiki keelte alla kinnitatud pabeririba punaste ja mustade tähistega. Parem käsi mängib kord keelte keskel, siis taandub äärele. Paistab, et kui helistada keeli punasest ribast seespool, kõlab pill mahedalt ja kui väljaspool, äärel, siis kiledamalt.

A. Arak kasutab ka sellist kandle puhul ebatüüpilist mänguvõtet nagu tremolo ning paneb rõhku meloodia dünaamikale, tõusudele-langustele. Mõne loo jooksul vahetab ta aeg-ajalt helistikku. See on üks võimalus varieerida viisi.

A. Araku kanneldajakarjäär on kestnud üle 30 aasta. Raske otsustada, kas pidada teda asjaarmastajaks või professionaaliks, igal juhul tunneb ta artistile omast vastutust publiku ees, et etteaste jätaks parima mulje. Kandlekasti ühte nurka mahub ka esinemisriietus: eest metallhaakidega hall kampsun rahvapärase mustriga ja must kaabu. Tihti palutakse teda esinema kokkutulekutele, vastuvõttudele, sünnipäevadele, pulmadesse, kandlepäevadele. Ta on mänginud eesti kultuuri tutvustavail üritusil Rootsis, Saksamaal ja Jaapanis.

Heldur Vaidla on põline Juuru elanik. Ta elab isatalus, varem töötas kolhoosi autojuhina. Kirjandusmuuseumis on temast jälg kuue 1987. aasta salvestise kujul: "Roosiaias", "Kaheduuri polka", "Sangaste valss", "Mulgimaal", "Üks vanamees raius üht jämedat puud", "Kord kõndisin ma halja aasa peal” (RKM, Mgn II 4020, 4021). Tollal, kui valmisid salvestised, oli ta 45 aastat vana, nüüd siis 65 , viimased kolm aastat pensionil. Ütleb, et pensionipõlves mängib pilli palju tihedamini kui enne.

Tema kodus on pillidel lahe põli: lõõtspill, akordion, kaks bajaani ja karmoška seisavad rivis erilisel riiulil, mandoliini koht on puhvetikapis klaasi taga, G-duuri häälestusega rahvakannel seisab ootevalmilt laual. Enda sõnul mängib ta lõõtspilli juba 60, kannelt aga 40 aastat. Seega algas ta pillimehekarjäär juba enne kooli. Karmoškal tõmbas ta ühe vene viisi oma versioonis; teistel pillidel, kohati kaasa lauldes, eranditult eesti rahvalikke lugusid.

Kandle mängimiseks on Heldur Vaidlal plastmassist lipits, pilli hoiab pikkade keeltega enda poole. Kandlel ta ainult mängib, laulma hakates võtab kätte akordioni või lõõtspilli, mida oli mänginud juba tema isa. 
Tallinna kanneldaja Jaan Olt on teine, kelle mängitud kaks lugu, "Koduke” ja "Vengerka", salvestati veerand sajandi eest (RKM, Mgn II, 3867). Ta jutustas, et isakodus Porkunis ei tulnud kandlemängust midagi välja. Proovis, aga ikka jättis jälle sinnapaika. Isa ja õde mängisid, aga tema pingutused läksid vett vedama. Nüüd ta mõtleb, et põhjuseks võis olla tema vasakukäelisus: ta üritas viisi tõmmata parema käega, nagu teised ees tegid, aga käsi ei kuuletunud. Hiljem, õppides Tallinnas, muretses ta endale kandle, ning hakanud viisi mängima vasaku käega, sai varsti selgeks kõik lapsepõlves pähe kulunud lood. Teooriat tunneb Jaan Olt algkooli muusikatundide ulatuses. Noorpõlves on ta esinenud mitmel rahvamuusikafestivalil, nüüd mängib tutvusringis.

Abielludes õpetas ta mängima oma abikaasa. Nii on nad juba kolmkümmend aastat mänginud duetina. Abikaasa Ülle on käinud muusikakoolis ja õppinud klaverit. Tema ülesandeks on valmistada spikrid iga loo ja kummagi kandle jaoks eraldi, sest tema spikker asub parema, mehe oma vasaku käe all.

Lood, mis Jaan Olt esitas minu palvel soolona, kõlasid mõneti ebakindlalt. "Koduke" ja "Vengerka", mis on salvestatud 1984. aasta festivalil, ei tulnud kohe meelde. Veidi otsinud, sai ta järje peale ja mängis mõlemad reipalt maha. Abielupaar on koostanud oma repertuaari nimekirja, milles sisaldub 108 rahvalikku laulu. Neil on ka väike omakoostatud laulik repertuaari põhivaraga.

\section{Eksperiment: asjaarmastajad ja professionaalid}

Ringsõit ja kohtumised pillimeestega õnnestusid igati, välja arvatud minu salajane välitööde täiustamise kava jälgida nende tööd uue loo õppimisel. Valdavalt keskendub muusikateadus helindite analüüsile, olgu need siis graafilisel kujul noodikirjas, kõlagu elava ettekandena või helikandjalt. Tähelepanu alt jääb välja, kuidas kulgeb loominguline töö, mida instrumentalist teeb enne lõpptulemuseni jõudmist. See on ka mõistetav, sest loomingu keerdkäike tagantjärele taastada tundub lootusetu.

Mõtlesin läbi viia katse, mille käigus pillimehed oleksid proovinud mängida äsja kuuldud tundmatut viisi ilma ettevalmistuseta, lisades motiivile akordisaate oma harjunud maneeris. Arvasin, et nii avaneb ehk võimalus mõista, milline on nende mõttekäik harmoniseerimisel, milliseid akorde nad kasutavad; kas nad järgivad originaali täpselt või ilmub nende sõrmede alt isikupäraseid interpretatsioone; mil määral need versioonid järgivad originaali jne. Kokkuvõtlikult öeldes arvasin, et mul osutub võimalikuks kaasa teha uue loo õppimise protsess ja selle kaudu mõista põhimõtteid, millele on üles ehitatud eesti rahvalik muusika. 
Mul oli välja valitud neli vähetuntud viisi helilindilt, mille Kandle-Juss (Johannes Rosenstrauch) mängis sisse 1956. aastal Stockholmis. Need olid: "Vändra polka", tantsuviis "Kivikasukas", pärisorjuseaegne "Teopoisi künnilaul" ja vana polka Saaremaalt. Viimast on kasutanud Eduard Tubin klaveripala "Kandlepolka" loomisel (Rumessen 2003: 169).

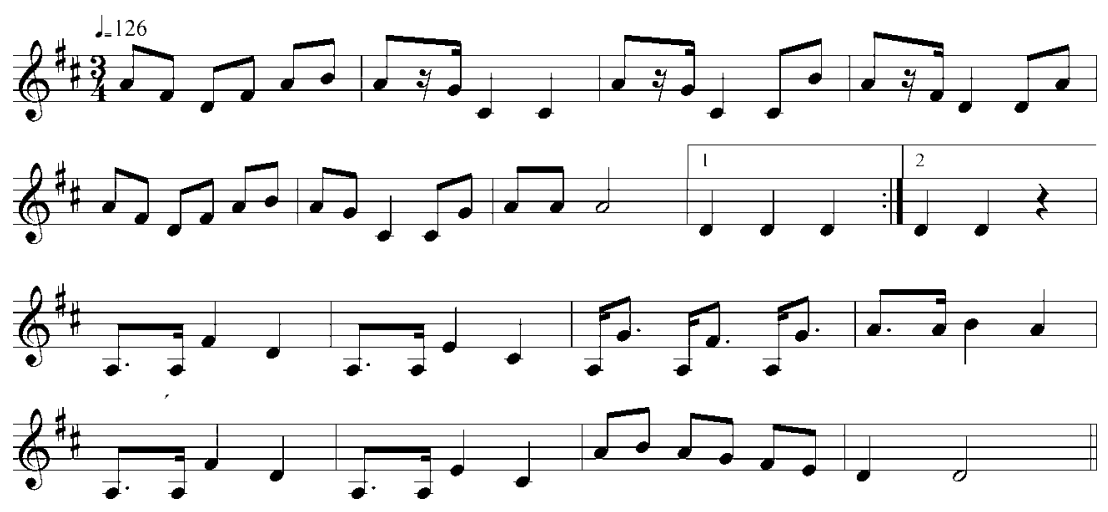

Näide 1. "Vändra polka".
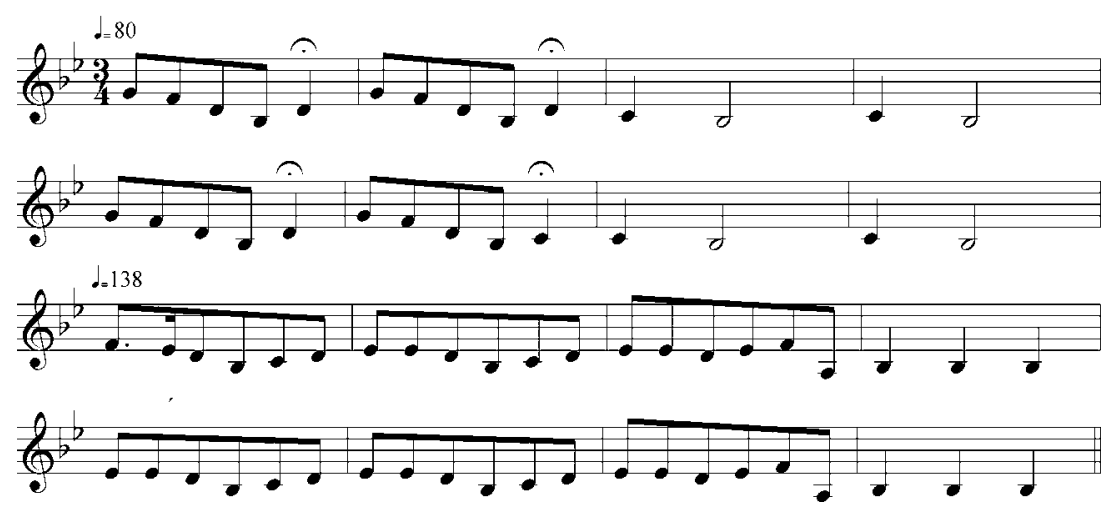

Näide 2. "Kivikasukas".

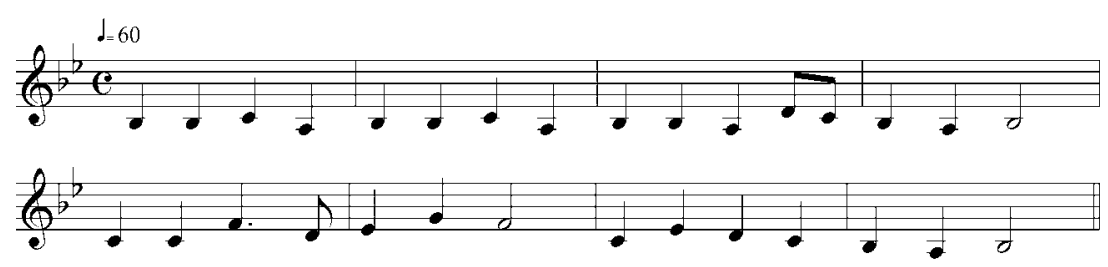

Näide 3. “Teopoisi künnilaul”. 


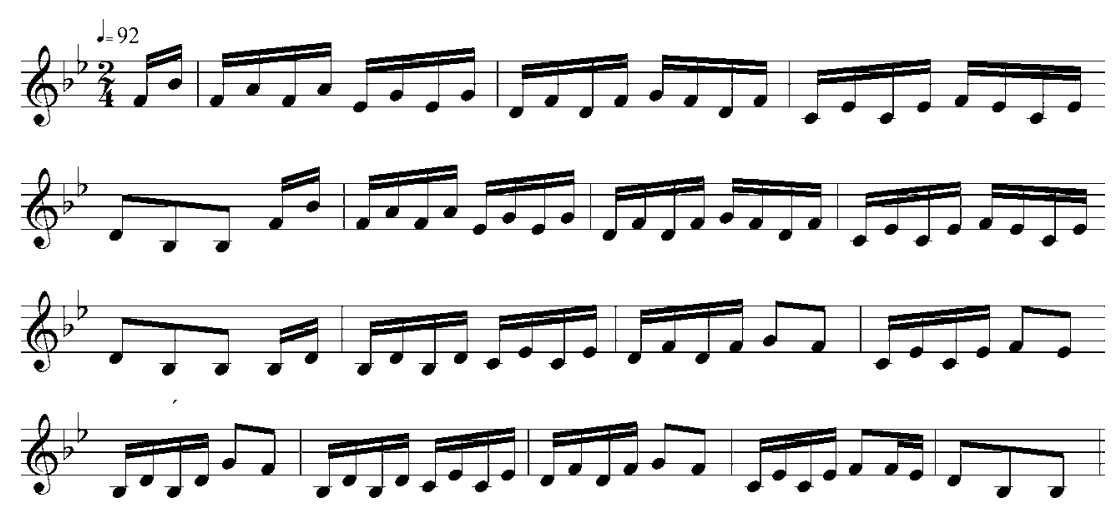

Näide 4. Vana polka Saaremaalt.

Nagu eeldasin, olid need lood tõepoolest kõigile võõrad. Täielik ootamatus oli aga see, et ükski viiest kanneldajast ei söandanud neid mängida, isegi mitte proovi teha. Saatekandle puhul toodi õigustuseks, et nemad mängivad üksnes “spikri” järgi. Minu vastuväide, et spikri nad ju valmistavad ise, aga lugu peaks selge olema varem, ei leidnud tähelepanu. Naljaga pooleks pakuti kuulata ükskõik millist, kuid tuntud lugu.

Viisikandlel mängiv Ilmar Hellamaa vabandas ennast välja, öeldes, et tema vanuses mehele käib üle jõu tundmatut viisi lennult meelde jätta. Iga loo oma püsirepertuaari hulgast - ainult nimeta! - esitas ta viivitamatult. Salvestamise ajal, kui üks lugu järgnes peatuseta teisele, heitis ta aeg-ajalt kiire pilgu taskuraamatusse, kus oli tema repertuaari nimekiri, ja jätkas hinge tõmbamata.

Nagu juba märgitud, on eranditult kõik pillimehed, kelle abil ma oma katse läbi viisin, asjaarmastajad. Nende repertuaari moodustavad enamasti sõjaeelsed rahvalikud laulud, mida nad esitavad kas lauldes pilli saatel või instrumentaalvariandina.

Et objektiivsemalt hinnata iseõppinud pillimeeste muusikalist taipu, andsin täpselt sama ülesande kolmele kõrgharidusega kandlemängijaile, kes töötavad väikekandle ja kromaatilise kandle õpetajana. Kõigi nendega kohtusin eraldi ja veel enne katset rahvamuusikutega. Tinglikult märgin neid kolme naissoost kandleõpetajat tähtedega A, B ja C.

"Vändra polka" ja "Kivikasukas" olid kõigile tuttavad, neid oli mängitud õpingute ajal. Ülesande selle osaga tuldi eeskujulikult toime.

Omapärase tõlgenduse sai mõtlik, tasakaaluka meeleoluga "Teopoisi künnilaul”, mida kõik kolm mängisid lustakas polkarütmis, kuigi ette oli antud 4/4 meetrum. Väheusutav, et see muudatus oli teadlik valik. Et kandlerepertuaaris domineerivad polka- ja valsirütmid, selgelt väljendatud elava ja tant- 
sulise tempoga lood, on kanneldajad tõenäoliselt alateadlikult häälestatud sellise karakteriga lugude mängimisele. "Teopoisi künnilaulu" juures aitas tempo tõstmisest, et mõtlik ja pikaldane viis võttis särtsaka polka kuju. Seda, kuidas teatud tempod on seotud kindlate meeleoludega, on kirjeldanud Johan Sundberg (1995: 180).

Neljandat, vana polkaviisi, soostus mängima ainult A. Viis oli talle üldjoontes teada. Laulsin paar korda ette, mõningase katsetamise järel ta sai kätte kindluse ja lugu hakkas kõlama. B ja C ei olnud seda meloodiat kunagi kuulnud ja neil ei jätkunud otsustavust proovi teha.

Huvitav oli jälgida, mis kukkus välja sarnaselt, mis erinevalt - just selle tagamõttega mu katse oligi korraldatud. Märgata oli erinev instrumendi valdamise tase ja suurem või väiksem fantaasialend. Mõistagi tahtsid kõik kolm tabada sobivaimat harmooniat ning väljenduse leidis see põhiastmete kolmkõladena, faktuuri jagasid nad rangelt meloodia- ja saatehäälteks. Saade oli kõigil ühte tüüpi: sekundeeriv, kahe või kolme heliga akordisaade.

Edukaimalt ülesandega hakkama saanud kandleõpetaja A oli lapsepõlves sageli kuulanud vanaisa ja isa kandle- ja akordionimängu. Alatihti oli ta isale viiulil kaasa mänginud. Rahvamuusika ja rahvalikud laulud olid tema lapsepõlve alalisiks saatjaiks. Kandlemängu hakkas ta õppima 24-aastaselt Viljandi Kultuurikolledžis. B-l ja C-l ei ole koduse musitseerimise kogemust.

Ei ole võimalik võrrelda iseõppinud rahvamuusikuid professionaalidega mingite objektiivsete kriteeriumide alusel. Proovin seda teha kaudselt. Kõik viis pillimeest, kellest oli juttu eespool, on professionaalid oma avalike esinemiste ja kutseoskuste poolest, kuid neil puudub teoreetiline ettevalmistus kas või elementaarse muusikalise kirjaoskuse ulatuses.

Seevastu kõrgharidusega professionaalsetele kandlemängijatele ei leidu tegevmuusikute seas nende võimetele vastavat kohta. Mõned kuuluvad mitmesuguste etno-popansamblite koosseisu. Nende põhitegevus on pillimängu õpetamine huvikeskustes ja laste huvikoolides. Rahvapidudel või perekondlikel koosviibimistel nad üles ei astu. Paradoksne, kuid rahvapilli õppimine kõrgkoolis annab peaaegu garantii, et inimesest ei saa rahvamuusikut.

Pillimeeste kogemus on kitsapiiriline, nad mängivad ainult hästi selgeks õpitud lugusid. Tundmatute viiside mängimiseks ilma põhjaliku ettevalmistuseta nende kogemus ei küüni, sest neil pole olnud vajadust seda oskust arendada. Muusikalise haridusega kanneldajate silmaring on laiem ja nende võime korrata äsjakuuldud viisi selle võrra suurem. Juba õpingute ajal on neil tulnud mängida noodist ilma ettevalmistuseta.

Tagantjärele vaadates paistab täiesti seaduspärane, et mu välitööde täiustamise kava kukkus läbi. Tõsiasja, et pillimeeste repertuaar koosneb rahvalikest lugudest, ei olnud ma veel omaks võtnud ja palusin neil mängida rahva- 
viise. Lisaks tegin veel selle vea, et pakkusin välja viisid ilma sõnadeta. Rahvapärane muusika on ennekõike laul, ja kuigi peaks kõlama ainult viis, helisevad laulusõnad pillimehe kõrvus nagunii.

Ilmeka, ehkki äärmusliku näite leiame Heino Tartese raamatus Põlvamaa lõotspillimängijad:

Tema mängimisel olevat olnud ainult üks viga: pillilood olnud liiga pikad. [Kõne all on Orava valla lõõtspillimängija Eduard Kõlli - G. J.] Ka 1953. aastal ühel isetegevuse ülevaatusel oli juhtunud nii, et Kõlli pillilugu ei tahtnud ära lõppeda, kuigi korraldaja andis talle korduvalt märku esinemine lõpetada. Kõlli oli selle peale ütelnud: "Uutke viil tsipakõnõ, mul jäi tuu viimäne värss viil mängmätä” (Tartes 2007: 69).

Ainult eriti andekad pillimehed on võimelised vabanema sõnade survest ja vabalt improviseerima mõnel tuntud teemal (Jussufi 2007: 94).

Kõigil mu respondentidel leidub kodus Lustilaulik, selle neljaköitelise kogumiku 2000. aastal välja antud esimene osa, mis sisaldab 382 peamiselt rahvalikku laulu koos viisidega. Raamat kannab kõikjal intensiivse kasutamise märke. Noodid on pillimeestele ülearused, noodikirja nad ju ei tunne, trükitekst aitab sõnu meelde tuletada või neid ära õppida, kui äsjakuuldud laul meeldima hakkas. Lustilauliku esimesele osale järgnenud kolme väljaannet paljude rahvaste lauludega pillimehed ei kasuta.

Väide, et pillimeestel puudub rahvaviiside ja rahvatantsuviiside mängimise kogemus, tundub veider, kuid ometi on rahvaviisid enamikule pillimeestest vaid möödunud aegade mälestis. Rahvatantsurühmad, mida on ju väga palju, harjutavad klaveri või helisalvestiste saatel, sinna pole pillimehel asja.

Peamine põhjus, miks mu palvele ei katsutudki vastu tulla, näib olevat siiski see, et õige pillimees hoidub kohmitsemast kõrvalise silma all. Enne ta üles ei astu, kui lugu on sulaselgeks õpitud ja kukub välja laitmatult. Arvatavasti oleksin pidanud valima katseks mõned rahvalikus stiilis tekstiga lood ja andma võimaluse need omaette selgeks õppida. Kuid see on tulutu tagantjärele tarkus.

Minu arvamus, et virtuoos, ja see sõna kehtib kõigi viie siin mainitud kandlemehe kohta, on võimeline mängima iga lugu igas olukorras, ei pidanud paika. Muusikute seas on tegelikult üsna tavaline, et mõni kulutab õppimisele meeletult aega, aga teisele jääb pala meelde esimese korraga.

Kontrollimaks oma järelduste paikapidavust, pöördusin tuttava keskealise naisterahva Inge poole, kelle hobiks on rahvalike lugude mängimine akordionil. Kandle ja lõõtspilli-akordioni rahvalik repertuaar kattuvad suurel määral, seega kogemuski on pillimeestel enam-vähem sama. Teised lood olid talle võõrad, aga "Kivikasukas" tuttav. Veidi meelde tuletades klahve sõrmitsenud, tuli 

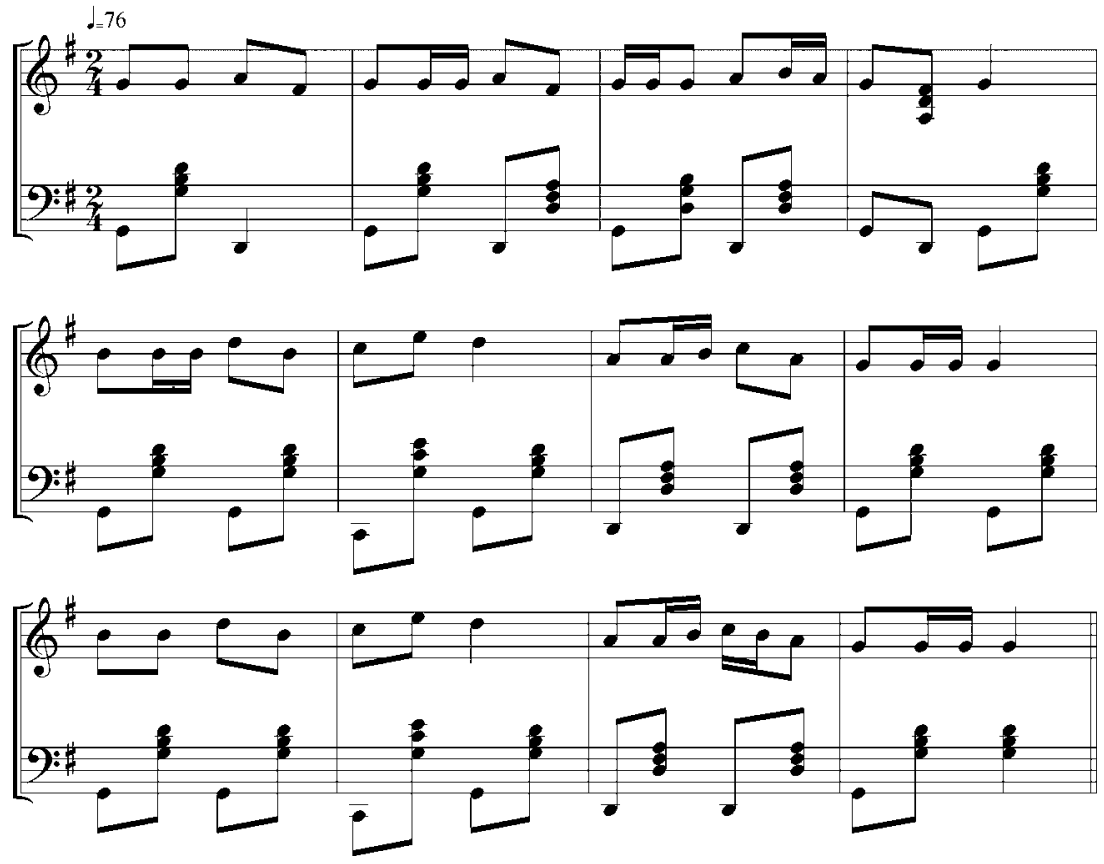

Näide 5. "Teopoisi künnilaul" Inge esituses.
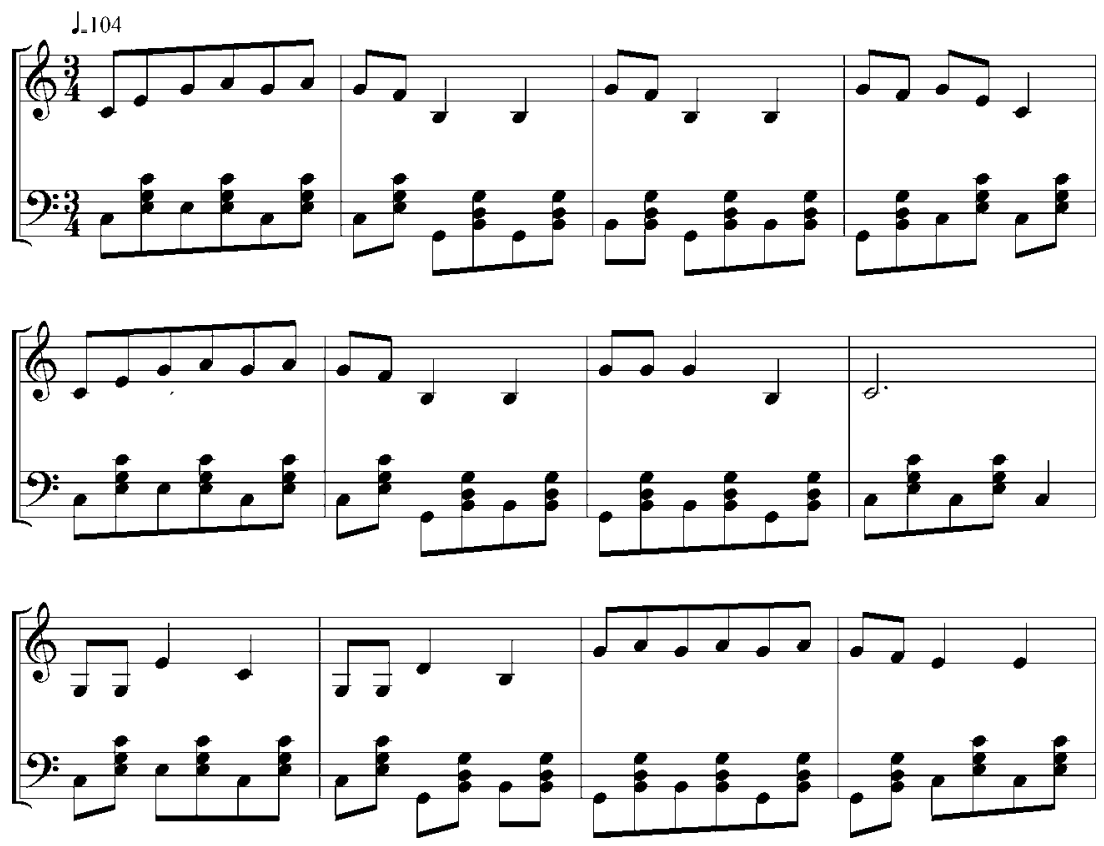


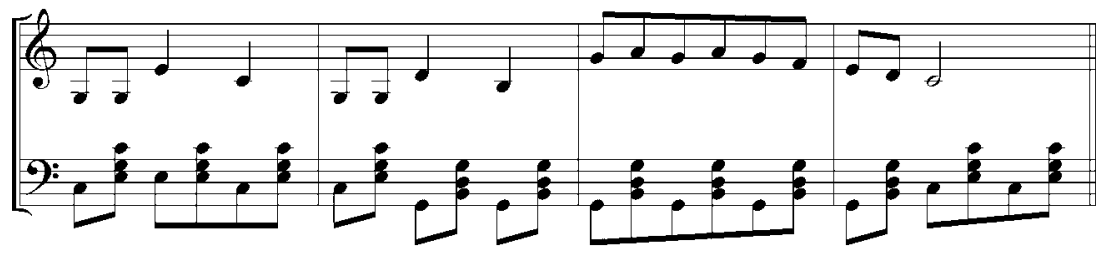

Näide 6. "Vändra polka” Inge esituses.

lugu laitmatult välja. Ülejäänud kolm lugu võtsime läbi samamoodi: algul näitasin motiivi paar korda ette, tema otsis klahvidel ning siis mängis julgelt ja ladusalt, kuidas meelde oli jäänud. Tulemuseks oli kolm sama rütmiskeemiga ja samas tempos välja peetud improvisatsiooni etteantud teemal. Algseid viise võis ainult aimata. Sealjuures säilisid rahvaliku muusika tunnused. "Vändra polka" saade seisis koos põhikolmkõladest (näide 6), bass ja akord kõlasid vaheldumisi nagu harilikult lõõtspillil. Saade oli ühtlaselt pulseeriv, mille tulemusena kadus polkale iseloomulik rõhuline taktiosa. Kohati võis ühes taktis esineda kaks erinevat harmooniat, näiteks toonika ja dominant. Muutusi tegi läbi kolmeosalise meetrumi rütmijoonis, eriti nähtavalt kadentsides. Takti esimeses, kohati ka teises löögis ilmus punkteeritud rütmi asemel ühtlaste kaheksandike liikumine, kuid takti kolmas löök jäi jagamata. Vorm jäi samaks $\mathrm{AB}$, kus A-osa on $4+4$ ja B-osa $4+4$ takti.

Katse Ingega veenis mind lõplikult, et mingeid võrreldavaid tulemusi ei maksa sel moel loota.

\section{Regiviisist rahvaliku viisini}

Keeruline oleks eraldada rahvaliku muusika rahvaloomingulisi kilde kindlate autorite loomingust, kui puuduks teave viimase kohta. Omaette ahvatlev oleks ülesanne leida mingeid niite, mis tooksid regiviisi juurest rahvaliku viisini.

Enamasti tunnevad inimesed oma rahva muusika ära eksimatult, olgu see siis ammu unustusse vajunud või nende kaasaegne stiil. Kuid tundmine on üks, seletada, mis erinevate ajajärkude muusikastiilidel vahel ühist on, hoopis teine asi. Äratundmine on intuitiivne sähvatus, olgu siis tegu muusika, inimeste või millegi muuga. Näitena lõik V. Saretokilt:

Jah, võib-olla ei olegi tänapäeval enam puhtaverelisi rahvaid - aga mispärast võin ma näiteks Chicago tänaval, selle miljonitelinna laupäevases rahvamurrus jalamaid ära tunda eesti lapsed? Millest see tuleb? Millest see tuleb, et Michigani järve ääres suvel on tuhandeid suplejaid, ma otse- 
kohe võin eraldada kas eesti või soome perekonna, enne kui nad hakkavad rääkimagi? Mina ei tea, millest see tuleb, aga nii see on (Saretok 1956: 102-103).

Sellist äratundmist on kogenud arvatavasti igaüks.

Järgmised näited ilmestaksid kauge muusika võimet äratada rahvuslikke emotsioone ning tunduda omasena. Tõnu Kõrvits on meenutanud:

Mehhikos juhtus selline lugu, et ühes kohas esinesid meile indiaanlased. Aga nende meloodiad olid täpselt eesti rahvalaulud. Oli selline tunne, et nad on ümberriietatud eestlased (Johanson 2009: 6).

Toomas Kõrvits täiendab samalaadse näitega:

Mul oli täpselt samasugune tunne Indias, Dehlis. Meie hotelli vastas oli tempel ja hommikuti kuulsin laulu, mis kõlas absoluutselt nagu eesti rahvalaul. Naised laulsid kõrgelt... See esitus oli niivõrd kihvt, et mul tuli judin peale - ei saa olla, et eestlased laulaksid kuskil templis. Niisuguseid momente, mil äkki avastad, et sa ei olegi oma muusikaga siin perifeerias, on väga palju olnud (Johanson 2009: 7).

Kord oli mul võimalus kuulata hindu meespreestri riituslaulu. Rabaval moel meenutas see vadja surnuitku, mis ei erine kuigivõrd setu itkudest. Väikese ulatusega motiiv; viimse võimaluseni pinges, ebaõiglusest kisendav hääl; kattuv emotsionaalne seisund - sellest aitab, et saada samastatud kuulaja silmis, kes ei tunne teksti. Hindu preester oleks nagu korranud sedasama vadja külanaise itku. Tegelikult nii oligi - mõlemad hüüdsid Jumala poole. Korduval kuulamisel tulevad lahknevused muidugi välja, kuid see on juba norimine.

Muusikateadus suudab helisid üles märkida, tabada nende seoseid, määrata stiile ja žanre, kuid kas on võimeline tabama ka neid rahvuslikke koode, mis päritakse eelnevatelt põlvkondadelt ja mis võivad peituda inimese oletatavas geenimälus? Muusika puhul tungib see kood eriti nähtavale. Kas oleks võimalik regiviise ja hilisemaid rahvalikke viise üksteisele vastandades jõuda selle koodi jälile? See ei ole kaugeltki kindel, kuid ma otsustasin proovi teha.

Lauluviisi otstarve on anda poeetilise tekstiga sobiv raamistus. Erinev värsiehitus tingib erineva muusikalise ülesehituse. Regilaulu parallelismide ja alliteratsioonidega küllastunud värss ning kvantiteedile toetuv meetrum esitab viisidele ühed, riimiline värss, olgu anonüümne või kindla autori loodu, teised nõuded. Salmilaulude viisid regilaulule ei sobi, samamoodi ei sobi regiviisid salmilauluga. Kuna regilaulu vorm oli omamoodi täiuslik ega olnud suuteline muutuma, jäi see stiil oma aja moodsa, stroofilise värsi jalgu ning pidi taanduma uuema rahvaviisi ees, mis omakorda hajus peale tuleva ja kiiresti 
üldiseks saanud rahvaliku stiili mõjuväljas. Selles ei tohiks olla kahtlust, et mingi aja püsisid vanemad ja uuemad rahvaviisid kõrvuti.

Raske on ette kujutada, et pikki sajandeid valitsenud vanem rahvaviis oleks taandunud uuema rahvaviisi ees jälgi jätmata. "Suurem osa uuematest rahvaviisidestki pole aga mingi konkreetse viisi ümberkujunduseks, vaid on kaudselt võrsunud varasema viisikihi pinnalt, tuues uuemasse viisitraditsiooni ühisjooni varasema viisikihiga" (Rüütel 1969: 22). Samamoodi võimatu on uuema rahvaviisi jäljetu taandumine rahvaliku muusika tulles. Peaksid leiduma mingid vahepealsed vormid, mis toovad möödanikust tänapäeva. Tundub, et Juhan Aavik (1965: 112), eraldades vanemate rahvaviiside seas nende hilisema ladestuse, oletas sedasama. See oleks ühendav lüli vanema ja uuema rahvaviisi vahel. Sealt edasi, uuemast rahvaviisist rahvalike viisideni jõuab raskusteta, kui meenutame, et mitmedki uuemad rahvaviisid, samuti ringmängulaulud, on sulandunud rahvaliku muusika hulka. Stiililised ühisjooned lubavad vaadelda uuemat rahvaviisi ja rahvalikku viisi tervikliku massiivina.

Otsides tunnusjooni, mis tõendaksid regiviiside esteetika edasikandumist nüüdisaega, rahvalike viiside ajastusse, lähtusin J. Aaviku mõtteliselt skeemilt: vanem rahvaviis, vanema rahvaviisi uuem ladestus, uuem rahvaviis, millele siis juba omapäi lisasin rahvaliku viisi lahtri. J. Aaviku termini "vanema rahvaviisi uuem ladestus" asemel kasutan mõistet "siirdevormiline rahvaviis", mis on muusikafolkloristikas juurdunud.

Nagu etnomusikoloogias tavaks, alustasin helikõrgusastmike süsteemi analüüsiga: määrasin kindlaks heliskaalad ja laadi. Rahvamuusikaga seoses mõistan laadi all tugihelide süsteemi, mille ümber rahvaviisid organiseeruvad.

\section{Vanem rahvaviis}

Vaadanud läbi ligikaudu kakssada rahvaviisi, leidsin mõned heliskaalad, mis vanema rahvaviisi puhul tunduvad olevat primaarsed. Kõik need heliskaalad on eranditult diatoonilised: ${ }^{1}$

1. ulatus on suur või väike terts tugihelist kõrgemal: I 2 3, I 2 3b;

2. puhas kvart tugihelist kõrgemal: I 234 ; 12 3, 4; 12 , 3, 4;

3. väike terts tugihelist kõrgemal ja suur sekund madalamal: IIb I 2 3b;

4. suur terts tugihelist üles ja väike sekund alla: II I 2 3;

5. puhas kvart tugihelist üles ja suur sekund alla: IIb 1234 ;

6. suur sekund tugihelist kõrgemal ja puhas kvart madalamal: IV III II I 2;

7. väike terts tugihelist kõrgemal ja väike terts madalamal: III II I 2 3,.

Herbert Tampere, analüüsides Mulgi-, Ojandi- ja Mõnistemaa vanemaid rahvaviise, leidis, et need tuginevad "kolmele tetrahordi (või triptahordi) liigile" 
(Tampere 1999: 45). Need langevad kokku ülalmärgitud alajaotustega 1, 2, 3, 4,5 ja 6.

Kõik eeltoodud heliskaalad mahuvad ühise heliastmiku raamidesse, mis näeks välja niimoodi: IV III II I 234 . Viisides esinevad heliskaalad enamasti osaliselt, harva leiab kõik astmed koos. Sagedasemad on kvardi ja kvindi ulatusega skaalad. Astmed II 2 ja 3 võivad olla madaldatud, tekitades järgmisi helijärgnevusi: I 2 3, 4; I 2b 3, 4; II I 2 3,. Neist esimese ja teise märgib ära ka H. Tampere (1999: 45). Kolmanda kohta leiame Heino Elleri ütluse, et eesti muusikale on iseloomulik helide järgnevus dooria helilaadis, kus juhtheli läheb toonikasse suure, mitte väikese sekundina (Ojakäär 2008: 521).

Madaldatud astmetega koos omandab heliastmik sellise kuju: IV III IIb II I 2, 2 3, 3 4. Niimoodi ilmuvad molli või duuri iseloomuga heliskaalad, mida eesti rahvamuusika puhul on esile toodud: "Klassikaline regilaul ei hõlma helilaadiastmikust rohkem kui 3-5 (6) astet; niisiis pole tegemist täieliku duuri, molli või mõne muu helilaadiga, vaid ainult nende tunnuste või elementidega" (Tedre \& Tormis 2007: 303).

Vanemate rahvaviiside meloodia liigub astmeliselt, harvade tertsihüpetega. Viisidel puuduvad kaunistused, heli kõrgus silbi vältel ei muutu. Viiside omaduseks on kvalitatiivne rütmika, st rõhuliste ja rõhutute lõikude korrapärane vaheldumine. Viiside rütmijoonised langevad tihti kokku. Viisi helide vältus on peaaegu alati ühesugune, teisi vältusi tuleb ette harva.

Tugihelide asetus üksteise suhtes määrab meloodia graafilise kujundi tüübi:

- meloodia ringleb tugiheli ümber;

- astmeline langev ja tõusev liikumine tugihelini;

- väikeste hüpetega (väike või suur terts) tõusev ja langev liikumine.

Vanemaid rahvaviise analüüsides õnnestus leida kolme-nelja heli pikkusi muutumatuid motiive, mis rändavad ühest viisist teise. Neid motiive võiks nimetada tüüpmotiivideks:

- kus liikumine toimub tugiheli ümber: 2 II I; 2 II 2 I; 2 I II I; 42 II I; 42 II 2; 42 II 5; 2 I III I;

- kus liikumine on astmeline nii tõusvas kui ka langevas suunas: 1234 5; 5432 I; 432 1; 32 I 2; I 232 jne;

- kus esineb langev või tõusev terts: 312 II I III; 1324 ; 135 jne;

- kus esinevad nii tõusev kui ka langev terts: 1342 ; 132 II; 354 2; 42 II; 2 II 2 jne;

- tõusva kvardiga IV I. 


\section{Siirdevormiline rahvaviis}

Viisid on pikemad kui vanema rahvaviisi ajajärgul ja nende ulatus on laiem, paisudes oktavini. Viisid ei välju ühe helistiku raamidest. Viisiarengu põhivõte on kordus. Võimalikud väikesed muutused, kus mõni veerandik või kaheksandik jaguneb pooleks, mitmekesistavad rütmi. Viisi vormiks on periood $4+4$, laused on kvadraatse struktuuriga. Mõnikord koosneb periood kolmest lausest $4+4+4$, kus teine lause kordab esimest. Meloodia liigub eelkõige astmeliselt, välistatud ei ole liikumine kolmkõla helide järgi ja tõusvad kvardihüpped nende järgneva täitmisega.

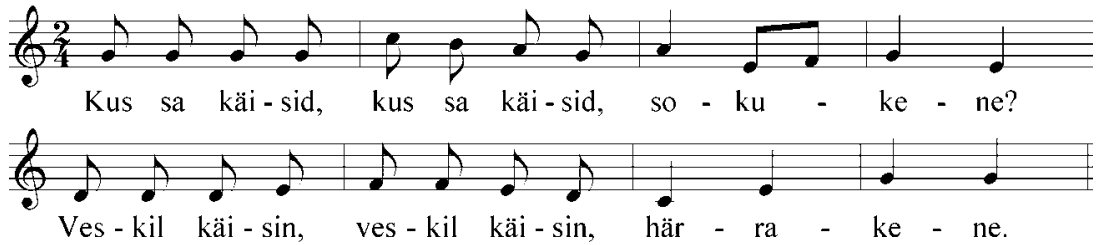

Näide 7. "Kus sa käisid, sokukene” (Aavik 1965: 112).

Paljud siirdevormilised viisid põhinevad kahe- ja kolmeosalisel meetrumil, mis seob neid polka- ja valsirütmiga. Siirdevormiline rahvaviis kuulub täiel määral mažoor-minoorsüsteemi helilaadide alla.

\section{Uuem rahvaviis}

Funktsionaalsele harmooniale rajanevad viisid on pikemad ja neid saab jagada fraasideks. Tegemist on arenenud vormiga, kus salm vaheldub kordussalmiga. Astmelise liikumise kõrval on tähtsal kohal liikumine kolmkõla ja V7 helidel. Esineb tõusvaid ja langevaid tertsi-, kvardi-, kvindi- ja sekstihüppeid. Tihti tulevad ette tertsist laiemad intervallid ja viiside ulatus kasvab pooleteise oktavini. Samuti on rütm vaheldusrikkam. Ühe loo sees kohtame erisuguste vältuste kombinatsioone, mis moodustavad mitmekesiseid rütmijooniseid. Enamik viise põhineb tantsu-, nt polka- ja valsirütmidel, mis toob kaasa kahe- ja kolmeosalise meetrumi. Mõned uuemad rahvaviisid ennetavad rahvalikke viise nii vormilt kui ka viisiehituselt.

Põhjalikumalt on uuemat rahvaviisi käsitlenud Ingrid Rüütel oma kandidaaditöös. Ta kirjutab:

Uuema laulustiili võidulepääs tähendas murrangut mitte üksnes värsivormis ja poeetilises stiilis, vaid ka viisides. Kui regivärsilise laulu mit- 
mes liigis olid viisid väheolulises, ainult sõnu saatvas funktsioonis, siis nü̈d saavad viisid täiesti iseseisvaks kunstiliseks väljendusvormiks, muutudes senisest retsitatiivist või poolretsitatiivist hoopis meloodilisemaks. Paljudele lauludele ühiseid rühmaviise asendavad tihti ainult ühe või paari lauluga seotud spetsiaalviisid. Muusikalised väljendusvahendid muutuvad sootuks. Uued viisid on pikemad, kusjuures valitseb kindlakujuline kvadraatne lauluvorm. Kõige tavalisemad on 4-fraasilised meloodiad (2 muusikalist lauset), tuleb ette ka pikemaid. Valdavaks saab suurem intervalliline ulatus. Varem oli tavaline terts ja kvart, kvint esines peamiselt vaid lüürilistes või meestelaulude viisides, mis olid pealegi regivärsiviiside enamikuga võrreldes põhiliselt uuema ilmega. Uuemas laulustiilis on väikseimaks ulatuseks kvint, palju esineb seksti, septimit, oktaavi ja avaramaidki ulatusi. Uuele astmele jõuab helilaadide areng. Kui üleminekukihti kuuluvad viisid on veel monoodilised, ei sisalda täielikku 7-astmelist gammat, ei tugine kolmkõlasuhetele ning ei kuulu seega mažoor-minoorsüsteemi, siis hiljem üldistub mažoor-minoorsüsteem oma põhiastmete funktsioonidega, juurdub funktsionaalne harmooniline mõtlemine. Levib ka sellel põhinev mitmehäälsus. Mitmesuguseid muutusi tekib meetrikas ja rütmis. Laulud on enamasti ühtlases taktimõodus, taktimõõduvaheldust kohtame sagedamini vaid viisi eri osade vahel (näit. ringmängulaulude eeslaul ja refrään). Teatud kõikumised võivad esineda mujalgi, kuid need kuuluvad pigem esituslaadi kui viisi põhiorganismi juurde. Väga levinud on mitmesugused tantsurütmid (labajalavalss, polka, reinlender, valss) (Rüütel 1969: 18-19).

\section{Rahvalik viis}

- Domineerib loomulik duur.

- Lihtne ja selge viis.

- Tantsulisus, valdavalt polka- või valsirütmis.

- Viis kulgeb ilma eriliste kõikumisteta: ei tõuse, ei vaju, ei tee dünaamilisi hüppeid. On välja peetud ühtlase jõu ja kirega.

- Enamik viise algab eeltaktiga.

- Viisidel puuduvad ilustused. Igale silbile vastab üks heli.

- Valitseb selge vorm: kvadraatne korduva kujundusega periood, $4+4,8+8$ või $16+16$, mis moodustavad AA ja BB struktuure, kus A vastab salmi-ja $\mathrm{B}$ refrääniosale.

- Meetrum on kaheosaline, rõhuline ja rõhutu osa vaheldumisi, või kolmeosaline, üks rõhuline ja kaks rõhutut osa. Need on lihttaktid $2 / 4$ ja 3/4 taktimõõduga ning liittaktid 4/4 taktimõõduga. 
- Rütmijoonised on lihtsad ja selged, sünkoop on harv nähtus.

- Viisid püsivad ühe helistiku raamides, kaldumisi esineb harva.

- Viiside ulatus on enamasti oktav.

- Tüüpiline on, et viis algab liikumisega tõusvas suunas, astmeliselt või kolmkõla ja mõnikord V7 helide järgi. Kordussalmis võib esineda suuri hüppeid järgneva täitmisega.

- Valitseb funktsionaalne harmoonia. Tonaalsusskeem on lihtne ja väga selge ning tihti piirdub ainult kahe funktsiooniga: kui salmi osal on eksponeeritud TD või TS, siis kordussalmi osal STDT.
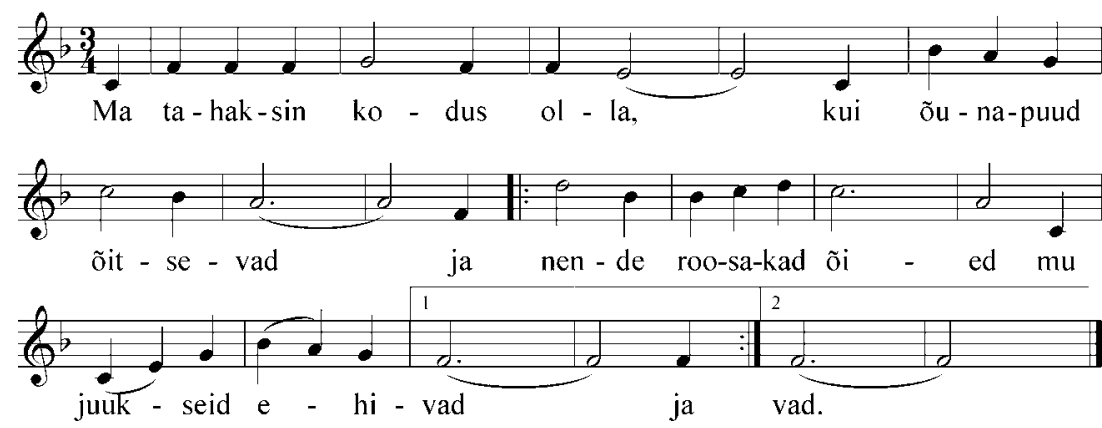

Näide 8. "Ma tahaksin kodus olla" (Lustilaulik 2000: 11).

Vanema rahvaviisi juures on teksti primaarsus võrreldes viisiga ning nn rühmaviisid üldtuntud tõsiasi: "Lühike viis järjest kordub, teksti värsiread arenevad edasi - sageli pikemaks lugulauluks" (Aavik 1965: 63). Rahvaliku laulu puhul on suhe teistsugune: viis on seotud ühe kindla tekstiga, kuid samal ajal nauditav ka ilma selleta. Kinnitust leiame H. Tamperelt: “... hakkas arenema harmooniline mõtlemisviis ja viisid ehitati üles juba enamasti mažoori või minoori põhikolmkõladele ja kvartsekstakordidele" (Tampere 2001: 13).

\section{Unemate rahvaviiside ja rahvalike viiside ühiseid jooni}

- Lihtne ja selge viis, mis jääb hästi meelde.

- Tantsulisus.

- Rütmijoonised on lihtsad ja äärmiselt selged, sünkoop on harv nähtus.

- Iga silp on viisistatud ühe heliga, kaunistused puuduvad.

- Kadentsid on paljudele viisidele ühised, näiteks: II 2 I, 2 I II I, 321 II I 2 I, 432 I jne. 
Ingrid Rüütel on selliseid seoseid iseloomustanud järgmiselt:

Ühisjooni vanas ja uues viisideladestuses pole sugugi nii vähe. Ometi on nendel kvalitatiivne vahe. Uus meloodika vaid kasutas vanu elemente uue loomiseks. Tuleb öelda, et eesti vanema ja uuema viisikihi ühisjooni omavad sageli ka eesti muusikatraditsiooni lülitunud laenulised viisid. See on seletatav sellega, et ühelt poolt nimetatud omadustega viisid kodunesid meil kergemini ja läksid enam käibele, teiselt poolt aga muudeti ka võõrama iseloomuga viise sageli kohalikule traditsioonile vastavalt (Rüütel 1969: 24).

\section{Menukaim muusikastiil}

Sõnaühend "rahvalik muusika" või "rahvalik laul" on üldiselt tuttav ja arusaadav, kõnekeeles on selle mõte selge. Seevastu kirjasõnas omandab see termin ühtelugu erisuguseid tähendusi. Mõni aeg tagasi kuuldud raadiosaates "Rahvalik laul" kõlasid ballaadilaadsed vokaalteosed kammerorkestri saatel ja rahvalaulude džässistiilis improviseeringud. Kõiki neid teoseid võis vägagi nautida, kuid see oli ikkagi kammermuusika ja džäss, millel puuduvad rahvaliku seltskonnastiili tunnused. Ma ei kujuta ette, et neid palu lauldaks seltskonnas.

Minu arvates tasuks raskuspunkt nihutada sõnalt, mis on iseenesest vaid häälikute kombinatsioon, selle taga olevale mõistele. Sageli on mingi eluala spetsiifilist terminit keeruline teise keelde ümber panna. Sõnale "rahvalik" leidub üsna mitu vastet: lihtne, tavaline, igapäevane, tagasihoidlik, vähenõudlik (Saareste 1959: 542). Segadus tekib siin aga sellest, et sõna populaar- (< ld populus 'rahvas'), mis annaks rahvaliku muusika olemust muidu hästi edasi, kannab rahvusvahelises traditsioonis teistsugust tähendust. Populaarmuusikat mõistetakse küll samuti kui lihtsa ülesehitusega, laiadele muusikalise hariduseta hulkadele arusaadavat muusikat (The New Grove 20: 128), ent sealjuures peetakse silmas peamiselt meie levimuusika mõiste alla kuuluvat.

Tõepoolest, kogu muusika, mida nimetame rahvalikuks, on väga tagasihoidlik ja lihtsa ülesehitusega. Viisid pole enamasti rahvaviisid, tihti hoopis välismaiste heliloojate looming, ja sõnad pole rahva-, vaid autorilooming, kuid selline lähenemine aitaks hajutada ka päritoluga seotud kahtlused: kas võõramaine viis võib ikka olla eesti rahvalik lugu. Väga hästi võib, kui viis sobib eesti seltskonnalaulu stiiliga. Seda kinnitab kaugelt saja aasta taha ulatuv kogemus. Uuemat tüüpi viiside tekkele avaldasid mõju vaimulikud laulud, eriti vennastekoguduste muusikaline tegevus, ning omal ajal jagamatult valitsenud liedertafellik koorilaul (vt Lippus 2008). Sellele on tähelepanu juhtinud ka V. Ojakäär: 
Rahvuslikud iseärasused, tingitud kohalikest muusikatraditsioonidest, on paljudes maades tänaseni säilinud. Näiteks on huvitav märkida soomlaste kiindumust slaavipäraselt minoorsesse meloodikasse ja harmooniasse, mistõttu tango on seal tänini ebaharilikult populaarne, mažoorsed kantrimeloodiad olid aga kaua tagaplaanil. Viimased on aga juba kaheja kolmekümnendaist aastaist peale nautinud populaarsust Baltimaadel, kus liedertafel-laulu külvatud harjumused on kehtestanud mažoorsete viiside eelisseisundi (Ojakäär 1983: 9).

Liedertafeliteks nimetatud Saksamaa meeste lauluseltsides harrastati koorilaulu

[---] mitte laulu kui kunsti pärast, vaid mõnusa meelelahutuse vahendina seltskondlikel kooskäimistel. Sellekohaselt nende repertuaari kuuluvad peamiselt kunstiliselt vähenõudlikud kergesisulised tuju-ja meeleolulaulud saksa järelromantikute magus-sentimentaalsest heliloomingust, milliseid nimetatakse seepärast ka tihti liedertafellikeks lauludeks (Kasemets 1937: 114).

See on hea rahvaliku laulu määratlus, mille kuulumise saksa rahvakultuuri juurde määrab sõnade keel.

Sellest, kui sügavale oli juurdunud liedertafel-laul, kõneleb asjaolu, et esimesed eesti professionaalsed heliloojad, rääkimata kümnetest asjaarmastajatest eesotsas Karl August Hermanniga, viljelesid seda vähemagi kahtluseta. Kestis aastakümneid, enne kui liedertafellik lihtsakoeline seltskonnalaul asendus kooride repertuaaris nõudlikumate, rahvuslikkuse ideed kandvate teostega. Uno Naissoo arvab 12.09.1950 dateeritud tekstis "Eesti valsist ja polkast":

[---] nii imelikult kui see kõlab, on meie oma rahvuslikud intonatsioonid meile endile küllaltki võorraks jäänud [---] tänu meie heliloojaile, kes on seni rahvalaulu kasutanud peamiselt ainult koori-ja soololauludes ( $k a$ instrumentaalmuusikas), mis sageli oma raskepärase käsitluse tõttu (A. Kapp, M. Saar) pole saanud rahvalikuks, on rahvas ise leidnud sissetunginud välismaiste intonatsioonide näol arusaadavama muusikalise väljenduse, mille küllaltki sügavat juurdumist ei või sugugi alahinnata (Ojakäär 2008: 308).

Etteheiteid on U. Naissool ka tema kaasaegsetele, rõhutatult rahvusliku suunitlusega heliloojatele nagu Edgar Arro ja Boris Kõrver, kelle looming,

vägikaika vedamine rahvasse jäänud vanade mõjudega on seni jäänud viljatuks (tõenduseks suured virnad "kõrgelt rahvuslikku" muusikat raamatu-ja noodikauplustes). Minu arvates tuleb rahva ümberkasvatamist 
teostada väga kavalalt, n.ö. märkamatult, hoolitsedes peale puhtrahvuslike käändude olemasolu (mis sageli on tõesti väga ära väänatud ja kunstlikuks tehtud) ka rahvaliku väljenduse eest [---]. Tuleks rohkem tähelepanu pöörata ilusa meloodia kujundamisele. Kas rahvalikud intonatsioonid ei võimalda seda? Ma usun, et võimaldavad küll! (Ojakäär 2008: 309).

U. Naissood häirib ka "harmoonilise külje üksluisus" ja värvikuse puudumine, mis väljendub tüütuseni tarvitatud paralleelses harmoonias "E. Kapi ja ameerika džässmuusika eeskujul".

Tuleb anda au U. Naissoole, kes on üsnagi karmilt, sealjuures aga täpselt iseloomustanud heliloojate abitust rahvale vajaliku muusika loomisel. Põhjuseks, miks see nii on, võib olla professionaalse helilooja võimetus ületada pikkade aastate kestel välja kujunenud isikupära piire. Lihtsakoeline ja pretensioonitu rahvalik stiil on olnud ja jääb edaspidigi nende osaks, kellele helilooming on kõrvalharrastuseks.

Rahvaliku muusika laenulisus on tülikas teema ammust aega. Üleriikliku raadioühingu häälekandja ajakiri Raadio kurtis 1935. aastal:

Viimase viie aasta jooksul pole plaaditööstused valmistanud enam mingisuguseid eesti plaate peale tantsutükkide ja lööklaulude. Ja needki pole eesti heliloojate loodud, vaid välismaiste autorite omad, ainult eestikeelsete sõnadega. Sellega pole need veel eesti plaadid (Raadio 1935: 366).

Need, kes teadsid, milline peab olema rahvakultuur, võitlesid võõraste kultuurinähtuste sisseimbumise vastu. Nüüdseks on lõplikult selgunud, et see oli asjatu võitlus. Kes oleks võinud tollal arvata, et seitsekümmend aastat hiljem on hulk välismaiste heliloojate loodud, "ainult eestikeelsete sõnadega" lööklaule hõivanud eestlase südameis aukoha otse isamaalike laulude naabruses.

Koorilauluga võrreldes on vajadus meeleolumuusika järele märksa suurem. Eesti oma heliloojad ei suutnud siis ega suuda ka praegu rahuldada nõudlust, olgu tahtmine kui suur tahes. Meeleolumuusika on määratlematu kooslus ning publiku maitse jätab ruumi nii Andrew Lloyd Webberi kui ka Kihnu Virve loomingule. Iseendastmõistetavalt läheb vaja ka erinevate võimetega artiste.

Tõrjuv mõtteviis tundub valitsevat kultuuriringkondades praegugi, ainult selle erinevusega, et tõrjutuks osutub puhtal kujul omamaine rahvalik muusika. Näitena võtaksin Toomas Anni esitatavad rahvalikud laulud. Paljud said selle laulja olemasolustki teada alles siis, kui ta kuulutati 2009. aasta meesartistiks. Tema CDde müügiedu tekitas sensatsiooni, millele ametivennad meelelahutustööstuse põllul, nagu teatati teleuudistes, reageerisid keeldumisega avaldada oma arvamust. Nähtavasti ei ole Toomas Anni telestaaride silmis täisväärtuslik muusik. 
Rahvalikku muusikat hindav publik avastas Toomas Anni plaadid aastaid tagasi, niipea, kui need müügile ilmusid. Seega on edu seaduspärane, mitte sugugi ootamatu. Muusikaeelistused on nagu usutunnistus, mida ei kuulutata iga nurga peal, mistõttu võib avastus, et tundmatu laulja lööb kuulsusi mütsiga, olla tõesti suur vapustus. Mu viiekümnendais eluaastais tuttav selgitas Toomas Anni fenomeni järgnevalt: "Neid laule on hea kuulata, selge eesti keel. Mind ei sega, et tema on lihtne kolhoosi traktorist, aga teised suured popstaarid. Nende kisa ja ulgumist ma ei taha kuulda."

Selle emotsionaalse arvamuse lahti mõtestanud, võime öelda, et Toomas Anni edu saladuseks on täpne ja selge diktsioon, loomulik ja pingutuseta laulmismaneer ja rahulikud, suuremate dünaamiliste kõikumisteta ühtlaselt kulgevad viisid. Juba 1930. aastatel leiti, et "laiemale kuulajaskonnale see lihtsus ongi mõistetavam ja arusaadavam kui kirglik lend suurte kunstiliste kõrguste poole ja rahutu tungimine filosoofiliste sügavuste sumedusse" (Kasemets 1937: 295).

Toomas Anni esinemisi või siis teda ennast on üleolevalt nimetatud äriprojektiks. Miks ka mitte, meelelahutus on toode, seda müüakse, seega kuulub ettevõtluse ja äri valdkonda. Mingil moel ei taunita ju Eesti Pärimusmuusika Keskust, kellele anti eripreemia Viljandi linnavalitsuse 2008. aasta ettevõtluskonkursil. Midagi halba ei ole selles, et artistid teenivad endale elatist.

Rahvalik muusika on populaarne muusikastiil ka kultuuritarbimise uuringu järgi, jäädes alla ainult igal sammul kilbile tõstetavale popmuusikale: viimast eelistab 38\%, rahvalikku muusikat 28\% Eesti elanikest. Džäss oma 9\% ja pärimus-, etno- ja folkmuusika 8\% kuulatavusega seisavad kaugel tagapool. Uuringu vormiks oli suuline intervjuu, vastajaid (vanuses 15-74) 1503 inimest (Kultuuritarbimine 2006). Kui aga võtta arvesse, et uuring haaras valikuliselt kogu Eesti elanikkonda, aga elanikest vähemalt neljandik, slaavi kultuuriruumi kuuluv osa ei hinda eesti rahvalikku muusikat kindlasti nii entusiastlikult kui eestlased ise, võib julgelt väita, et populaarsuselt ei jää rahvalik muusika popmuusikale alla.

Ametlikku statistikat tõendab ka Kanal 2 telekonkursi "Võsalaul 2009" tulemus. Tegemist oli varjamatu meelelahutussaatega, kus parimate laulude selgitamiseks korraldatud telefonihääletusel osales telekanali kinnitusel ligi 90000 inimest - ligikaudu 60 korda rohkem kui kultuuritarbimise uuringul. Selline telefonihääletus peaks olema võrreldav suurejoonelise rahvaküsitlusega.

Konkurss tõmbas kaasa nii rokkareid, räppareid, kantriharrastajaid kui ka inimesi, kelle ettekujutus muusikastiilidest on täiesti olematu. Ei maksa arvata, et televisiooni meelelahutuslik projekt pole etnomusikoloogile mingi uurimisobjekt - tähelepanu väärib kõik, mida rahvas loob. Rahvakultuuri salapä- 
rane ja seletamatu juurestik pressib kõikjalt läbi ja püsib kõigi muutuste ja moodide kiuste. Raamistus (ma mõtlen rütme, temposid, tämbreid, intonatsioone) võib muutuda, aga viiside esteetika järgib vanu radu, mida teadvustadagi ei osata.

Lauluvõistlus "Võsalaul 2009" oli selles osas tähelepanuväärselt õpetlik. Jätame kõrvale tekstid, samuti esituste visuaalse poole, mis enamasti mõjus ebameeldivalt, ning kuulame tähelepanelikult võistlustulest võitjana väljunud laulude viise. Finaali pääsenud kümnest laulust neli, lisaks veel üks väljaspool konkurssi esitatud laul, järgisid rahvaliku muusika stiili. Kui aga lisada, et kolm neist neljast jõudsid esiviisikusse, ei jää kahtlustki, mida hindab rahvas raadioeetri ja teleekraanid vallutanud moodsa levimuusika kiuste. Esikohale tulnud laulu ja ühe puhtakujulise kantriviisi võiks rahvaliku muusika kogumikku kas või kohe sisse kanda.

\section{Võsa laul}

Kristjan Reinvee
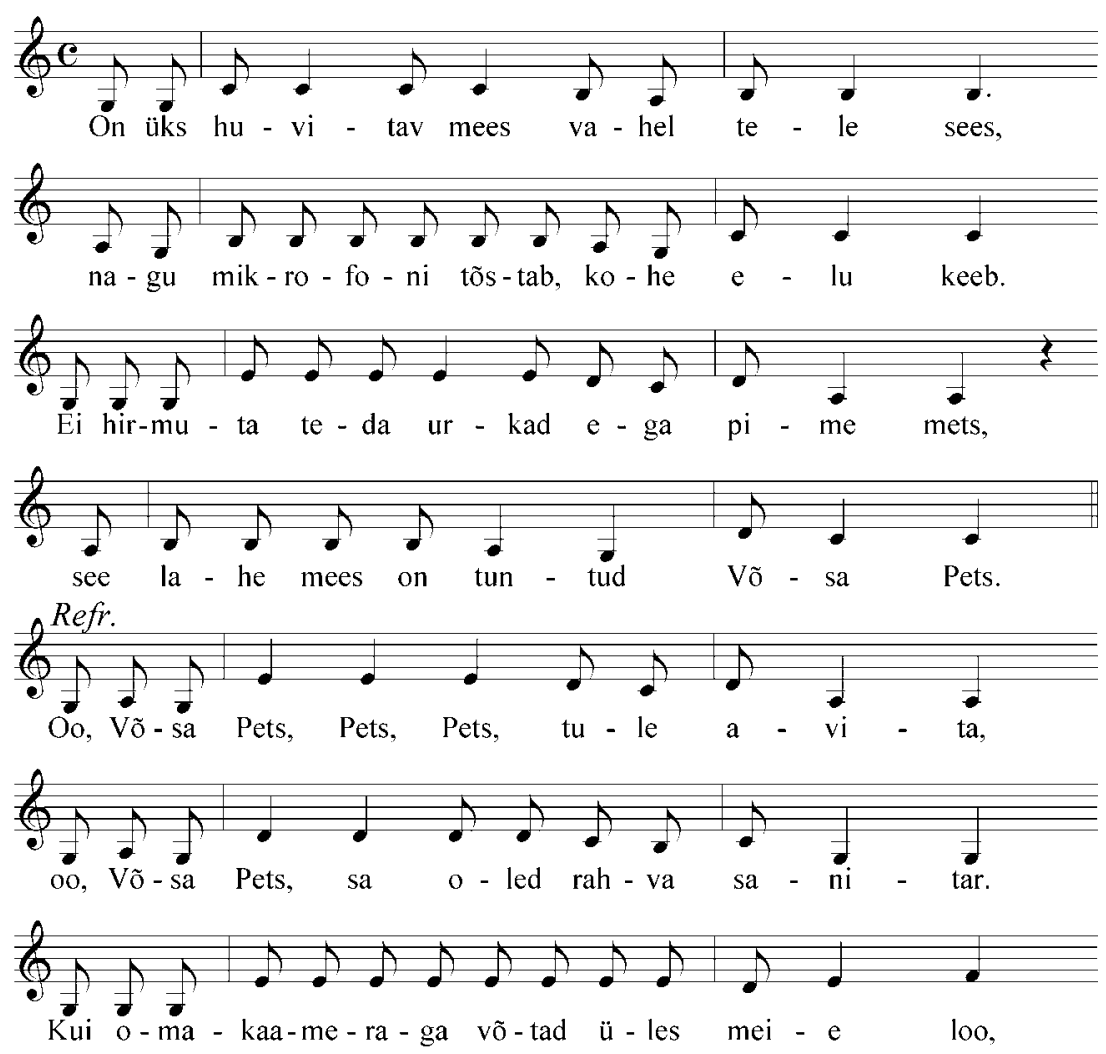


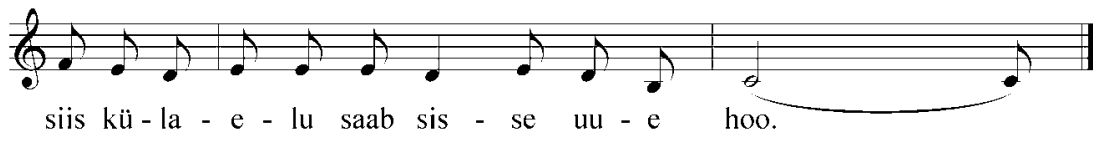

Näide 9. "Võsa laul".

Veel üks, kuigi mitte statistika ja arvudega kinnitatud tähelepanek: plaadipoes kuhjub maailma tunnustatuimate pop- ja džässansamblite ingliskeelne toodang allahinnatud kauba kastides, seal leiab Frank Sinatra ja hulga teisi superjärgu suurusi, aga eesti keeles sisse lauldud plaate müüakse täishinnaga. Rahvaliku muusika plaatide osa on tähelepandavalt suur, kuid sageli kohtab rahvalikke laule ka teisi muusikastiile harrastavate muusikute plaatidel. Kõhkluseta võib väita, et rahvalik muusika hõlmab eesti nüüdiskultuuris laialdase ala ja on üks neist elementidest, mille koosesinemine üksikisiku kultuurikaemuses annab tunnistust kuulumisest kindla etnilise rühma hulka. Mingil moel tuleks see vaieldamatu fakt kududa rahvakultuuri kangasse ka teaduse värvides - esialgu paistab ebakõla rahvahulkade ja asjatundjate tunnustuse vahel teravalt silma. Väga võimalik, et niimoodi vaikimisi, kedagi solvamata, püütakse inimeste muusikalist maitset kallutada kunstipärasemate valikute poole. Kuid Artur Rinne kirjutab:

Viimase sõna ütleb sellegipoolest rahvas, kuigi tema ilumeelt on proovitud kallutada nii ja teistpidi. Huvitav, et armastatud lauludel on ka oma vastased, ja seda siis, kui need pikemaks ajaks rahva südamesse kõlama jäävad. See kõlajõud kui pinge tekitab vastupinge. Ent neid "mitmekümneaastase habemega lööklaule” (nende laulude vastaste väljend) ei taha rahvas kuidagi mineviku kolikambrisse heita.

Oma arvukatel kontsertreisidel mööda meie väikest vabariiki ja lugematuil kohtumisõhtuil maa-ja rannarahvaga on mul ikka tulnud nende lihtsate inimeste soovil oma kava täiendada lauludega, nagu "Kodukotus”, "Mets mühiseb”, "Vana vokk”, "Rukkiväli”jpt (Rinne 1973a: 21).

Pöörates pilgu tagasi 1930. aastate keskpaika, aega, mil tema aastakümneid väldanud lauljatee alles algas, meenutab A. Rinne:

Muidugi tahtsin ma tol ajal kangesti laulda ooperiaariaid ehk siis raskemat sorti vokaalpalasid, nagu Mussorgski "Väepealikut" või Rahmaninovi "Saatust”. Nii esitasin kord Viljandis meeskoorikontserdil need kaks ülalmainitud pala. Publik küll eriti vaimustust ei tundnud, ent aplausi ikka jätkus, nii et sai veel lisaks Figaro kavatiini maha laulda. Aga kui ma siis teises osas publiku tungival soovil rahvalike lauludega välja tulin, läks 
saal alles elama. Pärast kontserti tulid mõned eakamad mehed lava taha, surusid kätt ja üks neist (tolleaegne linnaisa) lausus: "Tore, tore! Ma ütle, laulul peap ikka oma vunk man olema, et tuu kargap otse südamede kinni, tiip tuju ääks, nagu olles toobi kanget ôlut ärr joonu” (Rinne 1973b: 79).

Möödunud on seitsekümmend aastat, aga eesti inimeste arvamus ühtib siiani Viljandi linnaisa omaga. Kogesin seda Tartu rahvamuusikapäevade kontserdil, kus niipea kui lõõtspillimängija tõmbas lahti rahvaliku loo, hakkas publik innukalt kaasa laulma. Rahvamuusikat oli kuulatud, esinejale aplodeeritud, kuid innustuse kutsus esile rahvalik laul.

1935. aastal ilmunud Eesti rahvaviiside antoloogia I osa esmaväljaande eessõnas lubas koostaja Herbert Tampere:

Käesolevaga alustav antoloogiate seeria tahab anda läbilõike eesti muusikalisest rahvakultuurist selle kõigis avaldusvormides. Sellisena see peaks pakkuma ainet: rahvakultuuri harrastajaile, heliloojaile kui ka folkloristlike teadustega tegelejaile - viimastele vähemalt kataloogina eesti rahvamuusika rikkalikest varandusist (Tampere 1999: 3).

Antoloogia koostamine jäi H. Tamperel teatavasti pooleli, esimesele osale teisi ei järgnenudki. Siiski võib olla kindel, et ka H. Tampere, rääkides "eesti muusikalisest rahvakultuurist kõigis selle avaldusis", oli kaugel mõttest võtta Tallinna öölokaalides esitatavaid lööklaule rahvakultuuri osana. Tol kaugel ajal oli rahvalik muusika veel uurimata ala ning omaette nähtusena alles tuure kogumas. Tänapäeval on olukord kardinaalselt teine ja oleks aeg heita pilk rahvaliku muusika kujunemisteele.

\section{Ajalised kontuurid}

Tihti on uuema, stroofilise rahvalaulu, aga eriti rahvaliku laulu edukäiku kujutatud esivanematelt päritud kultuuri hülgamisena võõra kultuuri kasuks. Rahvaliku muusika kujunemise, aga veel enam tänapäevani kestva rikastumise näide kinnitab otse vastupidist: laenud ei muuda kultuuri põhiolemust. Võõrad osised sulanduvad omaenda kultuurikehasse ning omandavad sugulasliku näo. Puudutades muutusi, mis on toimunud aegade jooksul eesti rahvariietega, märgib Gustav Ränk: “[---] uue omandamine ei ole mingi võõra mehaaniline ülekandmine või "laenamine", vaid esmajoones ikka uute sugemete sulatamine oma vanade kultuurielu traditsioonidega" (Ränk 1949: 170).

Õigustatud on küsimus, kuivõrd on eesti rahvaliku muusika kujunemist mõjutanud saksakeelse kultuuriruumi muusikatraditsioon. Viimase arengus 
omakorda näeb tihedat seost kogu Euroopas järk-järgult valdavaks saanud uuetüübilise, refrääniga lauluga. Näiteks Hispaania villancico, refrääniga külalaul, mis levis ka Lõuna-Ameerika mandrile, ulatub tagasi 16. sajandisse. Saksa seltskonnamuusika oma paikkondlike iseärasustega, mille moodsaid variante tuntakse nimetuse all Volkstümliche Musik, võttis kuju 18. sajandi lõpukümnendeil. Kahtlemata on eesti rahvalik muusika jõudnud tänapäevase seisuni selsamal üleeuroopalisel rajal. Kõrvalmõjudeta kultuurinähtust ei ole lihtsalt võimalik ette kujutada. Ilmekas näide oleks soome rahvapärane muusika, millel on selgesti äratuntav idapoolne, vene kõlavärving (Ojakäär 1983: 9; soome populaarmuusika arengust vt ka Rautiainen 2005: 151).

Karl Leichter on artiklis "Muusikakultuur Eestis XVIII sajandil" täheldanud, et 18. sajandi balti aadlidaamide seas oli hoos lauluharrastus ning nad laulsid meeleldi sentimentaalseid eestikeelseid laule. Eriti armastatud olid "Tiiu tasane ja helde" ja "Minu rõõm oli Roosi". Esimene neist trükiti Saksamaal 1784. ja teine 1787. aastal. "J. Petri² arvates oli enamiku maal elavate "sakste" muusikaline maitse suurelt osalt ümber kujunenud eesti rahvusliku maitse järgi" (Leichter 1968: 20). Paistab, et kultuuriline mõjutamine ei olnud ühepoolne, nagu üldiselt arvatakse - härrastelt talurahvale -, vaid teatud määrani vastastikune nähtus.

18. sajandi lõpukümnendeid puudutab Christian Hieronymus Schlegeli ${ }^{3}$ teade kellegi 17-18-aastase eesti tüdruku kohta, kes puistanud "vanu laule nagu käisest". Samuti oli see tüdruk tõlkinud saksa laule suure kergusega eesti keelde ja leidnud neile sobiva saksa viisi (Leichter 1991: 19).

Juba 16. sajandi keskpaiku, nagu jutustab Balthasar Russow oma kroonikas, olid võõramaised laulud ammust aega Liivimaal au sees:

Ja kui ristimine oli talitatud, siis valmistati suur sööma- ja joomaaeg; siis istusid lauda junkrud ja sulased ning lasid end hästi kostitada ja enda eest hoolitseda. Pärast söömaaega alles hakati õieti rõõmsasti kaelustama, laulma ja tantsima. Ja see noormees, kes teiste seast kõige paremini oskas armulaule laulda ja trallitada, seda armastati ja hinnati kõige enam. Ning needsamad armulaulud olid kogu maailmast Liivimaale lennanud, kus neid suures aus peeti, ja igaüks, olgu noor või vana, õppis ja laulis neid suure hooga (Russow 1993: 84).

Arvatavasti esimene eestikeelsete sõnadega ilmalike laulude kogu, nimetusega "Mönned laulud", trükiti 1804. aastal (Tedre 2003: 238-239). 1860. aastal avaldas Johann Voldemar Jannsen oma ilmalike laulutekstide kogumiku Eesti laulik, millele 1862. aastal järgnes viisiraamat 120 saksa rahvaliku viisiga. Pole võimatu, et need J. V. Jannseni väljaanded mõjutasid eesti rahvaliku seltskonnalaulu stiili. Kogumikus sisalduv "Kuldne õhtupäike" on igal juhul vastu pi- 
danud siiani. Jättes kõrvale tekstide kunstilise taseme, saame öelda üsna kindlalt, et tendents meelelahutuslikkuse poole ilmnes niipea, kui koorikultuur oli saanud alla tugeva põhja. 19. sajandi lõpus trükiti nii nootidega kui ka nootideta ilmalikke laulikuid juba pidevalt. Tollal levima hakanud vallatu kupleelaulu näitena toob V. Ojakäär 1889. aastal (kordustrükina 1900. aastal) välja antud nootidega lauliku Naljakad laulud Eesti meestekooridele. Muusika pärines saksa heliloojalt, aga tekstid eesti autoreilt. Kogumiku esmatrüki eessõnas on väljaandja Jakob Martin Sommer kirjutanud:

Rahvale on naljakad laulud kontsertides väga meeldivad. Tõsine ja südamesse tungiv toonitükk, kui ta veel puudulikult saab lauldud, kaotab kuulajate ees mõju; muusikatundjatele on ilusa laulu vilets ettekanne muidugi valusaks kõrvalopsuks. Naljakates lauludes ei ole aga suurt muusikakunsti peidus; [---] sõnade nali [---] on naljalaulu ülesanne (Ojakäär 2000: 32).

Esimestest rahvaliku muusika helisalvestustestki, mis valmisid Esimese maailmasõja aegu Saksamaal, on tubli kolmandik - kolmeteistkümnest viis - isamaalikud koorilaulud, suurem osa, kaheksa numbrit, aga uuemad rahvalaulud, ilmselt siis külavahelaulud (vt Ross \& Nairis 2008: 353-360). Lauljaiks olid tsaariarmees teeninud ja vangi sattunud eestlastest sõdurid.

Valter Ojakäär (2000: 31) nimetab kümmekond 19. sajandi lõpu tuntuimat ühislaulu, millest enamik on praeguseni säilinud rahvalike viisidena. Eesti autorite laulude kõrval leiame ka Saksamaalt, Soomest ja Prantsusmaalt pärinevaid viise. Siiski on mõndagi neist peetud ehtsaks eesti lauluks. Ühe või teise laulu algkuju erineb meil tuntud viisist vahel vähe, vahel päris palju.

Oma aja ühislaulud on nüüdseks kolinud rahvalike laulude hulka, aga olemuselt on rahvalik laul seesama ühislaul. Silmas pidades osa, mida rahvalik muusika kannab seltskondliku elu sisustajana, võiks selle muusikastiili rahumeeli liigitada rahvamuusika hulka. Taive Särg märgib, et Eesti 19. sajandi lõpu kirjutistes "mõisteti [rahvalaule] tavaliselt kui rahva seas levinud erinevaid laule. Arvati, et rahvalaule võivad luua ka heliloojad - rahvalauluks muutub laul siis, kui see laiemalt kasutusele läheb" (Särg 2004). 19. sajandil Euroopas prevaleerinud 'rahvaliku muusika' mõiste "põhines kontekstil: sellega tähistati rahvaks peetava rühma hulgas tegelikult levinud muusikat, millel puudusid teised rahvamuusikale tarvilikuks peetavad tunnused (nt polnud traditsioonilises stiilis, anonüümne vm)" (Särg 2002: 39). Taive Särg on üks vähestest, kes on eesti rahvaliku muusika üle pead murdnud. Siiski on eesti muusika käsitluste puhul komplitseerivaks asjaoluks see, et vanem rahvamuusika ja rahvalik muusika on oma tunnuste poolest väga erinevad, mida ei saa öelda enamiku muu Euroopa muusikakultuuride kohta. Niisiis, kui rah- 
vusvahelises traditsioonis nimetatakse rahvamuusika tunnustega autori- ja laiatarbemuusikat folk-like või folksy music ja Volkstümliche Musik, siis viitab nimetus ühtlasi otseselt selle muusikalistele allikatele. Selles mõttes ei ole eesti rahvalik muusika folk-like.

Külapillimees näeb asju teisiti kui igakülgsete andmetega varustatud vaatleja. Pillimees mängib lugusid, mida on kuulnud lapsepõlvest peale, tema meelest see ongi rahvamuusika. Tal pole aimugi, et üks viis on Franz Schuberti, aga teine Johannes Brahmsi looming. Samamoodi teadmatuses viibivad enamvähem kõik, kes armastavad rahvalikku muusikat. Juhtumisi võib keegi olla kuulnud ühe või teise laulu autorist, kuid tähelepanu sellele ei osuta, aga ennast asjaga täpsemalt kurssi viia pole tal vähimatki vajadust.

Rahvaliku muusika teed märgistavad sõlmpunktid oleksidki rahvalaul, ringmängulaul, külavahelaul, võõramaine, enamjagu saksa rahvalik laul ning oma aja moodne tantsu- ja kantrimuusika. Kindlasti ei ole järgnevus nii range ja kasin, nagu paistab paberil, ning ega ole ka kogu rahvalike stiilitunnustega muusika, mis kunagi kõlas laulu ja pillilugudena, jõudnud meie päevadeni. Samuti on üksjagu keerukas ülesanne eraldada rahvaliku muusika peavool algseiks koostisosadeks. "Rahvalaulude ja rahvalike laulude vaheline piir on ebamäärane ja nende eristamine komplitseeritud,” on I. Rüütel (1980: 357) märkinud.

Külavahelaulude kaalu omaaegses ühiskonnas valgustab Märt Raud raamatus Eesti perekond aegade voolus:

Inimesed olid kinnistatud koha külge ja avaliku arvamise eest ei olnud võimalik põgeneda. Keeled olid kurjad. Kui saadi kellegi kohta ebameeldivaid andmeid, olid külalaulikud kohe platsis - ta peale tehti pilke-või lorilaul. Poisid tegid seda tüdrukute ja tüdrukud poiste peale. Nii tekkis kohapealse koloriidiga rahvaluule. Neid laule lauldi külavahel, isegi selle enese kuuldes, kelle kohta see käis. Neid koostati ka kollektiivselt (Raud 1961: 54).

Külavahelood on rahvalooming kõige puhtamal kujul. Hilisem rahvalike tunnustega muusika seondub kindlate autoritega ja jõudis enamiku inimesteni raadio ja heliplaatide vahendusel. Need olid sageli välismaised lööklaulud, millele olid sobitatud eestikeelsed sõnad ja mille algne funktsioon oli rahuldada restoranide ja tantsusaalide tarbeid.

Paljude rahvalike laulude ringlusse tuleku aega on võimalik üsna täpselt kindlaks määrata. Näiteks "Sonny-boy" läks rahva sekka 1929. aastal, mil Al Jonsoni esitatud helilooja Ray Hendersoni laul filmist Laulev narr (The singing Fool) "pani naised kinos nutma”, nagu märgib Valter Ojakäär. Aega viitmata tehti viisile emakeelsed sõnad ja laul on siiani vastu pidanud. "Lõbus õllepruu- 
lija" pärineb August Conradi laulumängust Omal jalgel, mille August Wiera lavastas Vanemuises enne Esimest maailmasõda. ${ }^{4}$ Billy Hilli "Vana vokk" ("The old spinning wheel”) pärineb Artur Rinne 1934. aastal salvestatud heliplaadilt. Lastelaulu "Mehikene metsas" leiame Engelbert Humperdincki ooperis Hänsel ja Gretel, mida mängiti Estonia teatrimaja valmimise puhul 1913. aastal (Ojakäär 2008: 589).

Valve Saretok, meenutades oma kooliaega 1920. aastate Valgas, kirjutab:

"U kamina" ja "Otshi tshornaja" kadusid meie salongidest, kus mõnd aega leelutati siis "Ich hab' Fräuln Helen baden sehn" või "Nur eine Nacht sollst Du mir gehören", mis vaheldus hoogsalt ameerika jazziga "Yes, sir, that's my Baby". Kuni viimaks me kõik laulsime patriootlikku "Viljandi paadimeest" või "Üksainus õis ei tohiks olla palju...”. Aga sinna läks veel palju, palju aastaid (Saretok 1956: 116).

Rahvustunde tugevnedes vajusid võõrkeelsed, sageli väga ilusa meloodiaga laulud unustusse. Püsima jäid ainult need viisid, mida varustati uute, emakeelsete sõnadega. Jällegi tunnistus selle kohta, et laulusõnad on rahvaliku muusika alusmüür (Jussufi 2007: 93). Ka nii mõnigi vene romansiviis sai toreda eestikeelse teksti ja püsib rahvaliku repertuaari hulgas siiani. Näiteks olgu vägagi populaarsed "Kitarre käes ja mantel üle õla" või "Tule ääres istun mina".

Kui kantriviisid 1930. aastate paiku Eestisse jõudsid, võeti nad kohe omaks. Põhjuseks võib pidada lihtsust ja vastavust eestlaste maitsele. "Eriti avaldub see meloodias, mis tüüpilistes kantrilauludes on voolav, kergesti lauldav ja emotsionaalne. Meloodia seos harmooniaga on tihe, sageli esineb akordihelidel liikuvaid käike. Laad on valdavalt mažoorne, minoorset esineb haruharva" (Ojakäär 1983: 70). Samaväärne, võib-olla veelgi tähtsam osa selle peaaegu silmapilkse edu juures oli eestikeelsel, arusaadaval ja kodusel tekstil. Õnnestunud sõnadega kantrilaulust sai seltskonnalaul, võõras päritolu ei seganud. Rahvalik repertuaar täienes pidevalt ning suurim teene selle juures on külapillimeestel, kelle väsimatud sõrmed raadiost ja plaatidelt pärit viise rahvale omaseks mängisid.

Samuti soodustasid moodsa muusika kiiret levikut raadioülekanded Tallinna restoranidest, mida 1920. aastate lõpul anti eetrisse laupäeval ja pühapäeval. Kes veel mäletaks, et rahvalike laulude au ja hiilgus "Postipoiss", "Mulgimaale", "Viljandi paadimees", "Vana vokk", "Kaugel, kaugel, kus on minu kodu", "Seal, kus rukkiväli lagendikul heljub" olid tollal restoranide menulaulud.

1920. aastate lõpuks oli siiski kodudes kuulatava ning tantsuõhtuil ja restoranides mängitava muusika vahele tekkinud selge lõhe: 
Seletus on lihtne: restoranipubliku maitse ei määranud nõudmist plaaditurul. Estonia Valges saalis kõlas moodne tantsumuusika, ringhääling kandis seda üle, kuid raadioaparaate oli nii vähe, et kodudes vändati grammofoniplaatidelt vanu häid rahvalikke laule, valsse ja polkasid (Ojakäär 2000: 93).

Ilmusid eesti omad rahvaliku stiili meistrid. Osa heliloojaist kirjutas laulusõnad ise, osa kasutas teiste kirjutatud tekste, mis aga sageli ei pärinenud ilukirjanduse varasalvedest, "vaid enamasti luuleandelistelt teatrimeestelt, ajakirjanikelt või lihtsalt mõnelt ladusa sulejooksuga asjahuviliselt" (Ojakäär 2000: 429). Minu võimuses ei ole ära arvata, miks mõni laul haagib ennast inimesele külge tugevasti, mõni teine nõrgemini, kolmas aga üldsegi mitte, kuid selles pole kahtlust, et meeldida saab vaid paeluvate sõnadega laul. Viis on laulu keha, sõnad tema hing.

Efektse näite selle kohta, milline laulutekst leiab tee rahva juurde, leiame Valter Ojakääru raamatust Sirp ja saksofon, kus on juttu ka 1954. aastal valminud raadiolavastusest Kevad murrab sisse, mille teksti kirjutas Uno Laht, aga muusika Gennadi Podelski:

Kurioosne lugu juhtus lauluga "Meremehe kiri". Luuletaja oli kirjutanud sõnad kerge muigega vanade lööklaulude sentimentaalsuse üle: "Sinu silmades mu laevukene randub, sinu süda mulle ankrupaigaks saab". Ent G. Podelski meloodia, G. Otsa südamlik esitus ning raadiokuulajate igatsus lihtsa ja sooja tundelü̈rika järele tegid "Meremehe kirjast" tõelise lööklaulu (Ojakäär 2008: 602-603).

Ajaraamid, mil rahvalik muusika kuju võttis ning mille jooksul kujunes välja selle igihaljas raudvara, omamoodi klassika, võiksid olla 19. sajandi lõpukümnenditest Teise maailmasõja lõpuni. Sealt edasi kõlas see kirju päritoluga muusikastiil valikuliselt kogu nõukogude aja, ilma et oleks oluliselt täienenud uute lugudega. Professionaalsed heliloojad (Edgar Arro, Leo Normet, Gennadi Podelski jt) komponeerisid tollalgi rahvalike tunnustega muusikat, kuid tekstide ideoloogilise suunitluse tõttu oli nende loomingu levik rahva seas piiratud. Suurem osa selle aja tänini püsima jäänud lauludest on rahvalike salmiseppade, nagu Albert Uustulnd ja Heldur Jõgioja, looming: ise pillimehed, tegid nad oma värssidele ka viisi.

Rahvaliku muusika juured peituvad nii sügaval kultuuripinnases, et isegi pool sajandit kestnud nõukoguliku kultuuri surve ei olnud võimeline seda kuigivõrd kahjustama. Artur Rinne, kirjeldades esinemist 1966. aastal Eduard Vilde nimelises kolhoosis, jätab ütlemata, mida ta laulis, aga ridade vahelt kumab läbi, et temalt oodati midagi muud. Mida nimelt, andis publik teada pä- 
rast kontserdi lõppu lauldud ühislauludega, mille hulgas oli kolhoosi esimehe lemmiklaul "Seal Mäeotsa talus":

Hiljem käis kogu õhtu mu kannul üks laulusõber. Laulgu ma "Ema südant”, "Kodukotust” jt. Mul ei olnud tahtmist neid mõtlikke viisikesi nii lustakalt häälestatud laudkonnale laulda, aga soovikontserdi tellija ei jätnud jonni. Ta viis oma tooli lava ette tantsupõrandale, tõusis toolile ja kutsus karusloomakasvatajaid kuulama temale südamelähedasi laule, mida Rinne esitada tahab, aga selle kuradima lärmi pärast ei saa lavale tulla. Peolised tulid nagu käsu peale oma toolidega ja istusid lava ette. Leo Tauts ja mina võtsime laval kohad sisse ning algaski kontsert. Keegi lülis välja saali täisvalguse ja tolles intiimses hämaruses laulsin terve tunni väsimust tundmata, kuna kuulajad elasid kogu hingest igale laulule kaasa. See oli omapärane miljöö. Tundus, nagu me kõik viibiksime tolles poolpimedas saalis kui mingis erilises magnetväljas (Rinne 1980: 109).

Lugusid tuleb järjest juurde, ja ehkki valdav osa neist vajub sedamaid unustusse, hoiab kõik üheskoos - püsiv ja ajutine - rahvalikku muusikat elujõulisena, vähemalt on siiani hoidnud. Sellega peaksingi piirduma. Teema on äärmiselt komplitseeritud ja möödaminnes seda lahti ei seleta.

\section{Rahvalik muusika identiteedi hoidjana}

Teine suunis, millega siirdusin välitöödele, seondub rahvaste identiteedi probleemiga. Etnomusikoloog saab siin tuua selgust, kas ja millisel määral muusika süvendab või vähemalt aitab ärkvel hoida rahva kokkuhoiutunnet. Muusika suurt mõju rahvaste identiteediloomele on toonitanud juba Anton Kasemets:

Sealjuures on muusika olnud tähtsaks teguriks rahva ühistunde säilitamisel kauges minevikus ja rahvusliku iseteadvuse äratamisel ning kasvatamisel võõraste võimutsemise ajastul. Need kaks asja - rahva ühtekuuluvuse tunne ja rahvuslik iseteadvus - ongi olnud selleks sisemiseks jõuallikaks, mis on kannud meie rahva läbi mineviku raskuste ning aidanud ta iseseisvale kultuurilisele ja riiklikule elule (Kasemets 1937: 7).

Maris Kirme on artiklis "Sibeliuse "Finlandia" - eestlaste rahvusliku identiteedi sümboleid" (1999) omaks võtnud rahvusliku muusika jaotuse Erkki Salmenhaara järgi funktsionaalseks ja substantsiaalseks. Esimene tähendaks tellimuslikku, aga teine heliteose süvaolemusest tulenevat muusikat. Need kategooriad viivad mõtted mõistete "eesti rahvalaul" ja "eesti rahvalik laul" juur- 
de. Järgides Herbert Tampere määratlust, peetakse viimase all silmas “trükitud (noodistatud) päritoluga ja enamasti teada oleva autori loodud laule, mille rahva laiad hulgad on küll omaks võtnud, kuid loominguliselt edasi ei arenda" (Kirme 1999: 47). Rahvalaul kattuks M. Kirme tõlgenduses substantsiaalsuse - süvaolemusest tuleneva muusika -, aga rahvalik laul funktsionaalsuse tellimusliku muusika - mõistega. Viimast iseloomustaks ennekõike see, et laulud on sageli sündinud laiade rahvahulkade tellimusel, oodatuna.

Samas leiame tõdemuse, et enamik funktsionaalselt rahvuslikke helitöid on seda ka substantsiaalselt. See käib eeskätt eestlaste rahvuslikku eneseteadvust jõuliselt toetanud patriootlike helindite, Jean Sibeliuse "Finlandia" ning Fredrik Paciuse "Mu isamaa on minu arm" kohta. Täpsustades võiks märkida, et F. Paciuse viis sai rahvale lähedaseks tänu J. V. Jannseni haaravatele sõnadele.

Mis puudutab rahvalikku laulu tavapärases seltskonnamuusika ja ühislaulu mõistes, siis tundub sellele tellimuslikkuse omistamine skeemi ette kirjutatud paratamatusena.

Rahvaliku laulu patriootlik sõnum ei jää sugugi alla eelmainitud J. Sibeliuse ja F. Paciuse helitööde omale, aga sageli isegi ületab neid. Kirjeldades 1944. aasta Eesti ohvitseride ja Tartu Ülikooli professorite kohtumist Jüri Uluotsaga, kus V. Ojakäär koos mõne kaaslasega viibis pillimehena, meenutab ta mõnda kohtumisele järgnenud koosviibimise ajal mängitud pala: "Kalevite kants", "Viljandi paadimees", "Saa vabaks, Eesti meri", "Mets mühiseb", "Postipoiss" jt (Ojakäär 2003: 408).

Rahvaliku muusika osa rahvustunde säilitamisel kajastub Siberisse korraldatud kogumisreiside andmeis. Samad laulud, mida lauldakse Eestis, on tuntud ka sealsete, 19. ja 20. sajandi vahetusel ümber asunud eestlaste hulgas. Rahvaliku muusika uuema osa, nagu "Kaugel, kaugel, kus on minu kodu", "Ma tahaksin kodus olla", "Läänemere lained”, tõid endaga kaasa küüditatud, kellelt need kandusid kohalike eestlaste hulka (Jürgenson 2002: 210).

Suurt rolli identiteedi kandjana mängis näiteks Tsvetnopolje eestlaste lauluansambel, kohalike kõnepruugis eesti folklor. Eestvedajana tegutses küla klubijuhataja Linda Tsirk. [---] Esineti erinevates koosseisudes, näiteks tegutses paralleelselt Linda Tsirgu vokaalinstrumentaalne perekonnaansambel ning õdede trio. [---] Mitmed lood olid üle võetud ka näiteks Läänes elavate eesti pagulaste repertuaarist. Nõukogudevastaste laulude eestikeelne esitus Siberi venekeelsele publikule on pikantne fakt, kuid taoline esitus oli kahtlemata Siberis ohutum kui näiteks Eestis. [---] Tsvetnopolje eestlaste lauluansambli puhul tuleb rõhutada tema rolli kohaliku eesti kogukonna konsolideerijana ning rahvustunde säilitajana (Jürgenson 2002: 212). 
Kahtlemata on rahvalik laul Siberi eestlastele tähtis rahvakultuuri osa, mis kinnistab ja aitab alles hoida kokkukuuluvustunnet päritolumaa rahvaga. Väljarändajate kohta, kes uuel kohal asuvad elama kompaktselt, on Aivar Jürgenson öelnud väga õnnestunult: "Kodu ei hüljata, vaid võetakse kaasa" (Jürgenson 2002: 116).

Kuidas on lood läänemaailma eestlaste juures, selle kohta puudub süsteemne ülevaade. Juhuslikud ja katkendlikud, enamasti ajakirjanduses ja televisioonis välgatanud andmed on liiga hõredad, et nende põhjal üldistusi teha. Kindel võib olla, et veel leidub pillimehi ja viisi kõlama hakates ka kaasalauljaid. Repertuaari ja esitusmaneeri kohta saab mingisuguse ülevaate, kuulates rahvaliku muusika ansambli Helin kahte helikasseti, mis on sisse mängitud 1993. aastal Leicesteris, Suurbritannias. Ühele on salvestatud kolmteist sõjaeelset, enamasti anonüümset rahvalikku laulu, teisele, nimetusega "Põlluteel", neliteist laulu. Viimaste hulgas leiame nüüdisaegsete eesti heliloojate loomingut. Erinevalt Eesti ansambleist, kus vokaalne ja instrumentaalne osa hoitakse enam-vähem tasakaalus, annab Leicesteri Helin selge eelistuse laulule.

Üks Ukraina eestlaste koori Sõleke liige jutustas laulupeo teleintervjuus, et nende kuulajatele meeldivad kõige enam "Kaugel, kaugel, kus on minu kodu" ja "Ma tahaksin kodus olla". Erinevalt kodumaa kooridest, kus lihtsakoelisi rahvalikke laule ei laulda, ei hoia sealne koor neist kõrvale.

Nii mõnegi rahvaliku laulu, nagu "Teele, teele kurekesed", "Postipoiss", "Vaikne, kena kohakene", leiame ka EÜSLi Projektikoori5 repertuaaris aastail 2004.-2008.

Kodumaalt lahkusid Siberi, Lääne-Euroopa ja Ukraina eestlased eri ajal ja erinevail ajendeil, kuid alateadlik tung alal hoida sidet oma rahvaga, kriipsutada alla oma rahvuskuuluvust on neil ühine. Sellest kasvab välja soov laulda kodumaa laule. Tundub, et kodust kaugele sattunud inimestele saavad rahvalikud laulud sümboliks, mis avabki neile tee kooride repertuaari.

Traditsiooniliste kultuurivormide alalhoiu vajadust on Heino Susi põhjendanud järgmiselt:

Rahvuslus - kuigi mitte ilmtingimata ainus ühiskonnakorralduse põhialus - on hilisemas ühiskonnavormide arengus olnud üheks kandvaks põhitalaks. Minu arvates õigusega. Töötada oma maa arengu ja tuleviku heaks; olla uhke oma kirjandusele, oma muusikale; arendada, täiendada ja voolida oma keelt; aidata selleks kaasa, et oma maa kujuneks meeldivamaks eluasemeks oma rahvale - kõik see pakub sisu ja mõtet, mida raske mujalt leida. Kiindumus oma maasse ja oma rahva kultuuriloomingusse on tiivustanud arengut ja loomingut nii Eestis kui mujal (Susi 2000: 55). 
Kahtlemata sisaldab kiindumus oma maasse ka tunnustust tippheliloojatele, nt arvab enamik eestimaalastest, et eesti muusikud ja heliloojad on maailmatasemel (Kultuuritarbimine 2006). Kuid sagedamini tekib ühistunne kindlasti inimestel, kes avastavad, et nad oskavad laulda ja armastavad ühtesid ja samu laule, neid, mille elushoidmise eest hoolitsevad rahvalikku muusikat mängivad pillimehed.

\section{Pillimehed ning rahvaliku muusika olevik ja tulevik}

Pillimehi, kellega ma kohtusin, võib jaotada kolme rühma, võttes tunnuseks nende osa rahvakultuuri edasikandjaina:

- Pillimehed, kes täidavad koosviibimistel eestlaulja rolli. Neid tuntakse ja kutsutakse sisustama koduseid koosviibimisi ja rahvapidusid (Ilmar Hellamaa, Heldur Vaidla).

- Pillimehed, kes ei laula. Nad astuvad üles kontserdikavadega, leiavad rakendust rahvapidudel ja mitmesugustel esindusüritustel (Ilmar Tiideberg, Aivar Arak).

- Pillimehed, kes musitseerivad iseenda lõbuks perekonna ringis (Jaan ja Ülle Olt).

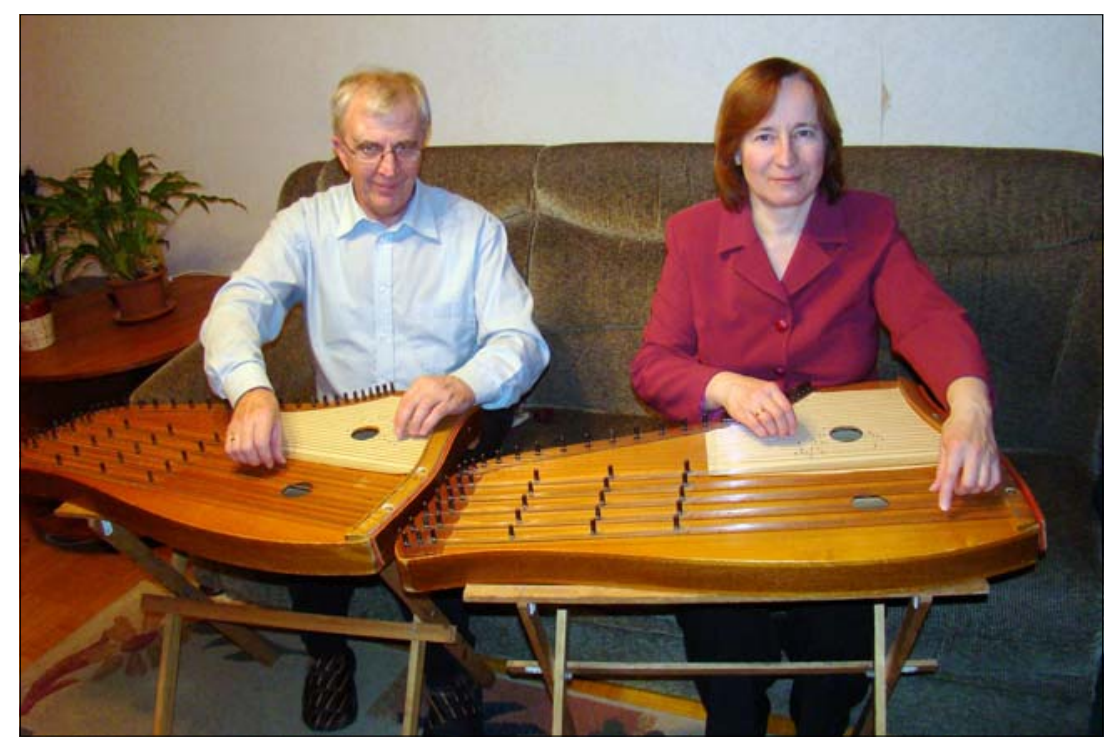

Jaan ja Ülle Olt. Foto erakogust. 
Kõik nad on muusikale pühendunud inimesed. Päritolult maalapsed, sirgusid nad sarnastes oludes ja neid kasvatati traditsioonide vaimus, niipalju kui seda võimaldas nõukogude võimu repressiivne iseloom. Kõigi nende vanemad, enamasti isa, aga ühel juhul ka ema, olid mänginud mõnda rahvalikku pilli. Need, kes mängivad ainult kannelt, kuuluvad haritlaskonna hulka - insener ja kaks arvutiõpetajat. Mitut instrumenti valdavad kaks pillimeest on töölised - autojuht ja puutöömees.

Vesteldes rahvamuusikutega mitte uudistajana, vaid kui võrdne võrdsega, leiab etnomusikoloog (sedasama võiks märkida kõigi folkloristide kohta) usaldusväärseid vastuseid vähema vaevaga, kui saadakse standardsete küsitluste ja ankeetide ning kogutud andmestiku analüüsi teel. Ei pruugi isegi küsida, vastused kooruvad välja iseenesest jutuajamise käigus.

Et heita valgust pillimeeste rollile rahvaliku muusika ja seega eesti identiteedi kujunemisel, valisin paljude võimalike hulgast kolm lihtsamat küsimust: kellest saavad pillimehed, kellele mängivad pillimehed tänapäeval ja kas vajadus pillimeeste oskuste järele on jätkuv või näitab languse märke. Rahva muusikakultuuri püsimise seisukohalt on need võtmeküsimused.

Kõik, kellega ma sel teemal vestlesin, ütlevad, et pillimeesteks saadakse kas juhuslikult või mingi sisemise tungi ajel. Järjepidevuse tähtsus perekonna liinis on väike ning kui seda ette tuleb, siis samuti juhuslikult. Kui keegi läheb isa jälgedes, siis vabal tahtel. Vanemate muusikaharrastuse jälgimine lapsepõlves võib olla impulsiks, mis kunagi edaspidi võib kellegi viia ühe või teise pilli juurde. Ühtegi siin artiklis nimetatud pillimeest ei ole lapsepõlves õhutatud, veel vähem sunnitud pilli mängima. Selline hoiak laste suunamisel kestab tänini. Nende endi pojad-tütred ei valda mingit pilli, veelgi enam, isegi ei ole üritanud pillimängu õppida. Naljaviluks keelte näppimine ja klahvide katsumine, millest lapsepõlves mööda ei pääse, ei tule muidugi arvesse.

Küsimusele, kas rahvalikku muusikat mängivate pillimeeste aeg pole läbi, kas nad on veel vajalikud uuema aja muusikastiilide kõrval, annab selgeima vastuse pillimeeste endi aktiivne tegutsemine. Ilmar Tiideberg on rahva ees mänginud umbes kolmkümmend aastat. Seniste avalike esinemiste hulga arvab ta 2100 kanti, seega 60 esinemist aastas, umbes kord nädalas. Minulgi kujunes kohtumine pillimehega põgusaks, sest järgmisel hommikul pidi ta esinema ühel kokkutulekul.

Heldur Vaidla kinnitas, et mängib pilli oma lõbuks, kuid meeleldi astub üles ka pidudel, sugulaste kogunemistel, sünnipäevadel - kui ainult kutsutakse. Tal on pisike märkmik, kuhu ta kannab sisse kõik oma esinemised. Ta mängib lõõtspilli, akordioni, bajaani ja rahvakannelt, kuid peokorraldajad soovivat enamasti lõõtspilli. Aasta jooksul koguneb Heldur Vaidlal umbes 60 avalikku esinemist. Lõõtspilliga on ta viimase kahe aasta jooksul väljas käinud 92 korda, seega rohkem kui korra nädalas. 
Pillimeeste tähelepanekuil annavad nende kuulajaskonna hulgas tooni vanemad, 40-aastased ja üle selle inimesed. Arvestades asjaoluga, et noortele mõeldud üritustele ja massiüritustele pillimehi ei kutsuta, ei saagi olla teisiti. Omaette küsimus on, kui vana on vanem inimene. Toomas Anni, hetkel hinnatumaid rahvaliku muusika esitajaid, ütles teleintervjuus, et tema kuulajad on vanemad, üle kolmekümnesed inimesed. Võrdluseks, saksa rahvaliku muusika tarbijatest pooled on 50-aastased ja vanemad (Shevy \& Kristen 2009: 14). Milline ka poleks seltskonna vanuseline koosseis üritusel, kus kõlab rahvalik muusika, vaevalt leidub neid, kes seda muusikat välja ei kannata ja ära lähevad. Omaette huvitav on küsimus: kas praegused kahekümnesed vajavad seda laadi muusikat kahekümne aasta pärast? Et vastata pädevalt, tuleb see aeg lihtsalt ära oodata.

\section{Kokkuvõtteks}

Käesolevas kirjutises olen püüdnud märgistada eesti rahvaliku muusikastiili tunnusjooni ja visandada ligikaudse jada, mis võiks seda stiili siduda varasema, tänapäeval käibelt taandunud rahvamuusikaga. Ülesannet jõuda mingi vaieldamatu tulemuseni ma endale ei seadnud. Eelkõige seetõttu, et alustada tuli peaaegu tühjalt kohalt. Muusikateadlased tegelevad rahvamuusikaga, rahvalik muusika on jäänud praktikute - artistide ja kirjastajate - hoolde. Üldise kultuuri kontekstis on rahvalikku muusikat käsitleva süsteemse ülevaate puudumine suur lünk. Kuid ainuüksi muusikateaduslikele meetodeile tuginedes ei ole võimalik mõista, milliste impulsside mõjul eestlaste eelistatuim muusikastiil on kujunenud just selliseks, nagu seda päevast päeva kuuleme. Lünga võiksid täita muusika-, ühiskonna- ja kirjandusteadlaste ühtse programmi alusel teostatud uurimused.

Rahvaliku muusika ning selle repertuaari raudvara väljakujunemise ajaks võib pidada ajavahemikku 19. sajandi lõpukümnenditest Teise maailmasõja lõpuni. Üldsõnaliselt võib öelda, et eesti rahvalik muusika on ulatuslike kultuurimõjutuste tulem. Sealjuures ei muuda veel tänapäevalgi aset leidvad laenud rahvaliku muusika põhiolemust. Võõrad elemendid põimuvad omadega ning saavad sugulasliku näo. Kinnitust leiab tõde, et kultuuri ei loo rahvad omaette, et kultuuriloome on juhitamatu protsess, paljude ajutiste sidemetega eri rahvaste vahel, mille vahetulemused võivad oluliselt muuta mingi konkreetse rahva kultuuripilti. Nii juhtuski, et mitmesuguse päritoluga muusikast moodustus rahvalik muusikastiil, kus on segamini külapoiste lorilaulud, lastelaulud, ringmängulaulud, isamaalikud laulud, Teise maailmasõja eelsed tantsulood ja šlaagrid, rahvamuusika kogu Euroopast, kantrimuusika, muusika- 
klassikute ja eesti heliloojate teosed. Kogu see kirju kogum kuulub rahvakultuuri kehasse lahutamatu ja orgaaniline osana.

Suurim teene rahvaliku repertuaari täienemise, levimise ja säilimise juures on külapillimeestel. Rahvalike pillimeeste repertuaari ja pillimänguharjumustega tutvumine näitas, et rahvalik muusika, see lihtsa ülesehitusega, ka muusikalise hariduseta inimesele jõukohane stiil on tänapäeval elujõuline kultuurinähtus. Vanem rahvamuusika, mida õpetatakse mitmesuguse tasemega õppeasutustes, kuulub pigem ametlike esinemisolukordade juurde, seevastu sünnipäevadel, pulmades, suguvõsa kokkutulekutel - sõna otseses mõttes rahva seas - kõlab aga rahvalik muusika. Ei saa küll öelda, et vanem rahvaviis oleks uuema ees kadunud jälgi jätmata - kui uuemate rahvaviiside kujunemine toetus vanemale viisikihile, siis uuema rahvaviisi ja rahvaliku viisi selged stiililised ühisjooned lubavad neid vaadelda tervikliku nähtusena. Pillimeestega korraldatud eksperiment näitas aga, et nende stiilide eraldusjoon on siiski määrava tähtsusega. Nii ei saagi eesti rahvalikku muusikat kirjeldada lihtsalt kui omaaegse rahvamuusika edasiarendust tänapäeva massimeedia-maailmas, nagu see on näiteks saksa rahvaliku muusika puhul. Eesti rahvalik muusika on nagu Eesti keerulise ajaloo peegeldus, rahvale omane ja südamelähedane nähtus ja sellisena üks eesti rahvusliku ja etnilise identiteedi komponente.

\section{Kommentaarid}

${ }^{1}$ Heliastmiku tähistamiseks kasutan etnomusikoloogias vastu võetud süsteemi, kus põhitoonist kõrgemal asuvad astmed märgitakse araabia, allpool asuvad aga rooma numbritega.

2 Johann Christoph Petri (1762-1851), saksa publitsist, ajavahemikus 1784-1794 oli mõnda aega Eestis koduõpetaja. Avaldas Saksamaal teoseid, milles leidub andmeid eesti talupoegade eluolu kohta. Väidetavalt valmistasid J. Petri teosed pinda pärisorjuse kaotamiseks Vene tsaaririigi Läänemere-äärsetes kubermangudes.

3 Christian Hieronymus Justus Schlegel (1757-1842), saksa literaat, pärast ülikooli lõpetamist aastal 1779 töötas Eestis koduõpetajana kuni 1796. aastani. Tema kirjatööd sisaldavad andmeid eestlaste ja eesti rahvaluule kohta, sealhulgas rahvalaule koos viisidega.

4 Omal jalgel. Naljamäng laulu ja muusikaga 6 pildis autorid on raamatukogude e-kataloogi ESTER põhjal Emil Pohl ja Heinrich Wilken.

5 EÜSL - Eesti Ühiskonna Saksa Liitvabariigis Projektikoor, praegu Euroopa Eestlaste Segakoor. 


\section{Allikad}

RKM, Mgn II = Eesti TA Fr. R. Kreutzwaldi nim (Riikliku) Kirjandusmuuseumi (nüüd Eesti Kirjandusmuuseumi) rahvaluule osakond, magnetofonilindistused (mono)

\section{Kirjandus}

Aavik, Juhan 1965. Eesti muusika ajalugu I. Stockholm: Eesti Lauljaskond Rootsis.

EE 1994 = Eesti Entsüklopeedia 7. Tallinn: Eesti Entsüklopeediakirjastus.

EKSS 1992 = Eesti kirjakeele seletussõnaraamat 3: 1. Tallinn: Eesti TA Keele ja Kirjanduse Instituut.

Johanson, Ants 2009. Kukerpillid, Eestimaa ilmamuusika. Muusika 5, lk 2-7 (http:// muusika.kul.ee/arhiiv/200905/lugu1.pdf - 17. märts 2010).

Jussufi, Guldžahon 2007. Kuidas kujuneb pillimeeste rahvapärane repertuaar. Mäetagused: Hüperajakiri 37, lk 87-107 (http://www.folklore.ee/tagused/nr37/jussufi.pdf - 17. märts 2010).

Jürgenson, Aivar 2002. Siberi eestlaste territoriaalsus ja identiteet. Tallinn: Tallinna Pedagoogikaülikooli kirjastus.

Kalda, Elo 2001. Eesti kandlemängijad ja kandlepalad Eesti Kirjandusmuuseumi Eesti Rahvaluule Arhiivi fonoteegis. Diplomitöö. Viljandi: Viljandi Kultuurikolledž.

Kasemets, Anton 1937. Eesti muusika arenemislugu. Eesti Lauljate Liidu väljaanne 95. Tallinn: Eesti Lauljate Liit.

Kirme, Maris 1999. Sibeliuse "Finlandia" - eestlaste rahvuslike identiteedi sümboleid. Teater. Muusika. Kino 3, lk 46-50 (www.temuki.ee/arhiiv/arhiiv_vana/Muusika/ 99mar_m3.htm - 17. märts 2010).

Kultuuritarbimine 2006. Eesti elanikkonna uuring. Kultuuriministeerium, 23. august 2006 (https://kule.kul.ee/avalik/esitlused/kultuuritarbimine/Kultuuritarbimine_2006.ppt - 17. märts 2010).

Leichter, Karl 1968. Muusikakultuur Eestis XVIII sajandil. Vahter, Artur (koost). Eesti muusika 1. [Muusikakultuuri ajalugu kuni Suure Sotsialistliku Oktoobrirevolutsioonini]. Tallinn: Eesti Raamat, lk 17-25.

Leichter, Karl 1991. Seitse sajandit eestlaste lauluteed. Kultuuriloolisi andmeid aastatel 1172-1871. Tallinn: Eesti Raamat.

Lippus, Urve 2008. Liedertafel'ist ja selle kriitikast. Labi, Kanni (toim). Paar sammukest XXIV. Eesti Kirjandusmuuseumi aastaraamat 2007. Tartu: EKM Teaduskirjastus, lk 113-135.

Lustilaulik 2000 = Kõiva, Inda (koost \& toim). Lustilaulik I. Eestlaste armastatumad seltskonnalaulud läbi aegade. Tallinn.

Ojakäär, Valter 1983. Popmuusikast. 2., täiend tr. Tallinn: Eesti Raamat. 
Ojakäär, Valter 2000. Vaibunud viiside kaja. Eesti levimuusika ajaloost 1. Tallinn: Eesti Entsüklopeediakirjastus.

Ojakäär, Valter 2003. Omad viisid võõras väes. Eesti levimuusika ajaloost 2. Tallinn: Ilo.

Ojakäär, Valter 2008. Sirp ja saksofon. Eesti levimuusika ajaloost 3. Tallinn: Ilo.

Raadio 1935 = Eesti muusika ja ringhääling. Raadio: Üleriiklise Raadioühingu häälekandja 237: 42.

Raud, Märt 1961. Eesti perekond aegade voolus. Stockholm: EMP.

Rautiainen, Tarja 2005. Populaarmuusika uurimisainena - teoreetilised ja metodoloogilised vaatenurgad. Ojamaa, Triinu (koost). Pärimusmuusikast populaarmuusika$n i$. Töid etnomusinoloogia alalt 3. Tartu: Eesti Kirjandusmuuseumi etnomusikoloogia osakond, lk 147-156.

Rinne Artur 1973a. Laulab Artur Rinne. Tallinn: Eesti Raamat.

Rinne, Artur 1973b. Laulud ja aastad. Tallinn: Ajaleht Kodumaa.

Rinne, Artur 1980. Ja kägu kukub raal.. Tallinn: Perioodika.

Rumessen, Vardo 2003. Eduard Tubin: Helitööde temaatilis-bibliograafiline kataloog ETW = The Works of Eduard Tubin:Thematic-bibliographical Catalogue of Works ETW. Tallinn: SE\&JS \& Stockholm: Rahvusvaheline Eduard Tubina Ühing.

Ross, Jaan \& Nairis, Maile 2008. Esimese maailmasõja aegsetest eesti salvestustest Berliini arhiivides. Keel ja Kirjandus 5, lk 353-362 (http://www.eki.ee/keeljakirjandus/Ross\%2C\%20Nairis.pdf - 17. märts 2010).

Russow, Balthasar 1993. Liivimaa kroonika. Tallinn: Hotger.

Ränk, Gustav 1949. Vana eesti rahvas ja kultuur. Stockholm: Eesti Raamat.

Rüütel, Ingrid 1969. Eesti uuema rahvalaulu kujunemine. Dissertatsioon filoloogiakandidaadi teadusliku kraadi taotlemiseks 1.-3. Tartu: Eesti NSV Teaduste Akadeemia, Eesti NSV TA Fr. R. Kreutzwaldi nim. Kirjandusmuuseum.

Rüütel, Ingrid (toim) 1980. Eesti uuemad laulumängud: Kogumik 1. Tallinn: Eesti Raamat.

Rüütel, Ingrid 2009. Kümme aastat Põlva rahvamuusikatöötluste festivali. Sirp 08.05.09 (http://www.sirp.ee/index.php?option=com_content\&view=article\&id=8746: kuemme-aastat-polva-rahvamuusikatoeoetluste-festivali\&catid=5:muusika\&Itemid $=12 \&$ issue $=3251-19$. märts 2010).

Saareste, Andrus 1959. Eesti keele mõisteline sõnaraamat = Dictionnaire analogique de la langue estonienne: avec un index pourvu des traductions en français II. Stockholm: Vaba Eesti.

Saretok, Valve 1956. Läbi uduliniku 1. Noore vabariigi koolis. Toronto: Orto.

Shevy, Mark \& Kristen, Susanne 2009. German Listeners' Music-Genre Schemas for International and Domestic Popular Music: Differences in Cognitive Associations Associated With Exposure to Country, Hip-Hop, Punk, and German Folksy Music. Paper presented at the annual meeting of the International Communication Association, 
Marriott, Chicago, IL, May 20, 2009 (http://www.allacademic.com/meta/ p301271_index.html - 11. märts 2010).

Sundberg, Johan 1995. Opetus muusikahelidest. Tallinn: Scripta Musicalia.

Susi, Heino 2000 [1962]. Rahvusriikidest ja demokraatiast. Grabbi, Hellat \& Iliste, Ivo \& Linnuste, Vahur (koost ja toim). Vaba Eesti tähistel: Valimik tsensuurivaba eesti mõttelugu aastaist 1948-64. Tallinn: Eesti Entsüklopeediakirjastus, lk 51-55.

Särg, Taive 2002. Rahvamuusika mõiste kujunemisest - "rahva" teaduste ja musikoloogia vahel. Ojamaa, Triinu \& Rüütel Ingrid (koost ja toim). Pärimusmuusika muutuvas ühiskonnas 1. Töid etnomusikoloogia alalt 1. Tartu: Eesti Kirjandusmuuseumi etnomusikoloogia osakond, lk 9-44.

Särg, Taive 2004. Rahvamuusika kontseptsiooni ja mõiste kujunemisest Eestis 19. saj. teisel poolel. EKM rahvaluule arhiivi ja TÜ võrdleva rahvaluule õppetooli konverents Ilumäel 26.-27. novembril Tartus ja Värskas. Teesid (www.folklore.ee/regilaul/konverents2004/taive.htm - 17. märts 2010).

Tampere, Herbert 1999. Eesti rahvaviiside antoloogia I. Tallinn: Eesti Keele Instituut.

Tampere, Herbert 2001. Eesti rahvalaule viisidega I. Tartu: Eesti Kirjandusmuuseumi etnomusikoloogia osakond (faksiimile 1935. aasta väljaandest).

Tartes, Heino 2007. Põlvamaa lõõtspillimängijad 1892-2007. [Saverna:] Heino Tartes.

Tedre, Ülo 2003. Eesti mees ja tema sugu XIX sajandi lõppriimilises rahvalaulus. Tallinn \& Tartu: Eesti Kirjandusmuuseum.

Tedre Ülo \& Tormis, Veljo [2007]. Uus regilaulik. Tallinn: SP Muusikaprojekt.

The New Grove 9 = Tyrrell, John (vastutav toimetaja) \& Sadie, Stanley (toim) 2001.The new Grove dictionary of music and musicians 9. Florence to Gligo. London: Macmillan \& New York: Grove.

The New Grove 20 = Tyrrell, John (vastutav toimetaja) \& Sadie, Stanley (toim) 2001. The new Grove dictionary of music and musicians 20: Pohlman to Recital. London: Macmillan \& New York: Grove.

\section{Summary}

\section{Folksy Music as a Part of Estonian Folk Culture}

Guldžahon Jussufi

Key words: circle song, folksy music, folksy song, player

In this text I have attempted to mark the characteristics of the Estonian folksy music style and to outline the sequence connecting this style to the earlier folk music that is no longer in use. Reaching an undisputable result was not my goal, mostly due to the fact that I had to start from almost nothing. Musicologists work with folk music, while folksy music has been left for practitioners - artists and producers. In the context of 
culture in general, the lack of systematic overview of folksy music is a considerable gap. However, based on musicological methods alone, it is not possible to understand the impulses that have influenced the Estonians' preferred music style to develop exactly into what we hear nowadays. Researches by scientists of music, society and literature, carried out according to a unified research program, could fill this gap.

It can be stated that in the broad sense the Estonian folksy music is a result of extensive cultural influences. At the same time the loans, still happening today, do not change the basic principles of folksy music. Foreign elements intertwine with elements already present and start to look familiar in the process. This asserts that nations do not create their culture in a vacuum; instead it is an uncontrollable process in which many temporary ties emerge between different nations and whose interim results can considerably change a nation's culture. Thus it happened that music of various origins blended into a folksy music style that is a mixture of mock songs, children's songs, game songs, patriotic songs, dance songs and schlagers from before the Second World War, folk music from all parts of Europe, country music, works by classical composers and Estonian composers. This colourful assemblage constitutes an inseparable and organic part of folk culture. Spontaneous circles of influence have been functioning always and everywhere, but nowadays the changes in culture come about with greater intensity and they are easier to recognise and to observe. 